\title{
The GH-IGF-SST system in hepatocellular carcinoma: biological and molecular pathogenetic mechanisms and therapeutic targets
}

Claudia Pivonello ${ }^{1}$, Maria Cristina De Martino ${ }^{1}$, Mariarosaria Negri', Gaia Cuomo ${ }^{2}$, Federica Cariati', Francesco Izzo ${ }^{3}$, Annamaria Colao ${ }^{1}$ and Rosario Pivonello ${ }^{1 *}$

\begin{abstract}
Hepatocellular carcinoma (HCC) is the sixth most common malignancy worldwide. Different signalling pathways have been identified to be implicated in the pathogenesis of HCC; among these, GH, IGF and somatostatin (SST) pathways have emerged as some of the major pathways implicated in the development of HCC. Physiologically, GH-IGF-SST system plays a crucial role in liver growth and development since GH induces IGF1 and IGF2 secretion and the expression of their receptors, involved in hepatocytes cell proliferation, differentiation and metabolism. On the other hand, somatostatin receptors (SSTRs) are exclusively present on the biliary tract. Importantly, the GH-IGFSST system components have been indicated as regulators of hepatocarcinogenesis. Reduction of GH binding affinity to GH receptor, decreased serum IGF1 and increased serum IGF2 production, overexpression of IGF1 receptor, loss of function of IGF2 receptor and appearance of SSTRs are frequently observed in human HCC. In particular, recently, many studies have evaluated the correlation between increased levels of IGF1 receptors and liver diseases and the oncogenic role of IGF2 and its involvement in angiogenesis, migration and, consequently, in tumour progression. SST directly or indirectly influences tumour growth and development through the inhibition of cell proliferation and secretion and induction of apoptosis, even though SST role in hepatocarcinogenesis is still opened to argument. This review addresses the present evidences suggesting a role of the GH-IGF-SST system in the development and progression of HCC, and describes the therapeutic perspectives, based on the targeting of GH-IGF-SST system, which have been hypothesised and experimented in HCC.
\end{abstract}

Keywords: GH-IGF1 axis, Somatostatin, Somatostatin receptors, Normal liver, Hepatocarcinogenesis, Hepatocarcinoma

\section{Introduction}

Hepatocellular carcinoma (HCC) represents the sixth most common cancer and the third leading cause of mortality for malignancy in the world [1]. HCC is the predominant type of hepatic carcinoma, accounting for $90 \%$ of liver primary malignant tumours [1-3]. The Barcelona Clinic Liver Cancer (BCLC) staging system is recommended by European Association for the Study of the Liver (EASL) and the European Organisation for Research and Treatment of Cancer (EORTC) for prognostic

\footnotetext{
*Correspondence: rosario.pivonello@unina.it

'Dipartimento di Medicina Clinica e Chirurgia, Università Federico II di Napoli, Via Sergio Pansini, 5, Naples 80131, Italy

Full list of author information is available at the end of the article
}

prediction and treatment allocation of $\mathrm{HCC}[1,4,5]$. BCLC staging classification is based on variables related to tumour stage (number and diameter of tumour nodules and presence of portal invasion and metastasis), liver function (Child-Pugh class) and general health status (performance status test), that define five groups of patients with $\operatorname{HCC}(0, A, B, C$ and D) and link these groups to a specific treatment strategy and a different prognosis $[1,4,5]$. In particular, according to BCLC staging system, the "stage 0" includes patients with very early HCC; the "stage A" patients with early HCC; the "stage B" patients with intermediate HCC; the "stage C" patients with advanced HCC and the "stage D" patients with endstage disease $[1,4,5]$. 
Hepatocarcinogenesis is a multistep process evolving from normal liver, through chronic hepatitis and/or cirrhosis and formation of dysplastic nodules, to HCC. Indeed, HCC rarely arises in non-cirrhotic liver (about $20 \%$ ), while it often develops on pre-existing cirrhosis (about $80 \%$ ), primarily due to hepatitis B virus (HBV) or $\mathrm{C}$ virus (HCV) infection or alcohol consumption. The aetiological factors (virus infection, alcohol consumption, genetic disorders of metabolism, hereditary hemochromatosis, tobacco smoking, aflatoxins, drugs and radiations) may vary depending on ethnic group or geographic area of the patients affected by this malignancy $[1,6]$. These evidences suggest that several pathological agents, able to induce liver damage, can stimulate an inflammatory and hyperproliferative response in hepatocytes by activating and/or inhibiting several cell molecular pathways. Liver damage, chronic inflammation and the hyperproliferative hepatocytes status predispose to the accumulation of genetic and epigenetic alterations that determine the development of HCC [6-15]. The types and the sequence of the occurrence of genetic and molecular alterations associated with hepatocarcinogenesis have not been fully clarified and they seem to be highly tumour-specific [16]. The commonly altered pathways in HCC include: IGF (in particular IGF2 and downstream mediators, as mTOR), p16/pRb (DNA repair pathway), p53/p21 (cell-cycle pathway), $\beta$-catenin, and trasforming growth factor (TGF) [6-18]. A schematic model of hepatocarcinogenesis is presented in Figure 1.

The GH-IGF-SST system is an endocrine system consisting of growth hormone $(\mathrm{GH})$, insulin-like growth factors (IGF1 and IGF2) and the relative associated carrier proteins and receptors, and somatostatin (SST), controlling human prenatal development and postnatal growth by regulating cell proliferation, differentiation and metabolism [19]. The liver occupies a central role in this endocrine system, because it produces many of its components and it is also a target of their actions [20]. Therefore, liver injury affects the function of GH-IGFSST system and, in turn, the alteration of GH-IGF-SST system may play a role in the development of liver diseases, such as cirrhosis, fibrosis and HCC [21].

The GH-IGF-SST system seems to play a role in the development of various malignancies, including HCC. Indeed, in several types of cancer, GH-IGF1 axis has been demonstrated to affect tumour cell proliferation, apoptosis and invasiveness, and tumour angiogenesis $[22,23]$. Changes in the expression pattern of GH-IGF axis have been reported in HCC, suggesting that this system plays a role in hepatocarcinogenesis [24]. Additionally, the activation of somatostatin receptors (SSTRs) may elicitate antitumoural effects through both direct (inhibition of cell proliferation and induction of apoptosis) and indirect (inhibition of cell proliferation and angiogenesis through the suppression of growth factors and growth-promoting hormones, such as $\mathrm{GH}$ and IGF1) mechanisms [25,26]. HCC has been reported to express SSTRs, although literature data about the antineoplastic effects of the somatostatin analogues (SA) in HCC are still controversial $[27,28]$.

The aim of this review is to analyse the role of $\mathrm{GH}$ IGF-SST system in the development of HCC, mainly focusing on the underlying biological and molecular mechanisms and on the possibility to target this pathway as a new treatment strategy in HCC patients.

\section{GH-IGF-SST system: an outline}

The GH-IGF-SST system is composed by three essential components: ligands (GH, IGF1 and IGF2, SST), receptors [GH receptor (GHR), IGF1 receptor (IGF1R), IGF2 receptor (IGF2R) and SSTRs)] and binding proteins $[\mathrm{GH}$ binding protein (GHBP) and IGF binding proteins (IGFBPs)].

$\mathrm{GH}$ is mainly produced and secreted in a pulsatile manner by the anterior pituitary gland and represents the main regulator of postnatal growth, by controlling cell secretion, metabolism, survival and proliferation $[29,30]$. GH promotes IGF1 gene transcription and synthesis in the liver, thus regulating the circulating levels of IGF1 [31].

GH secretion is strictly controlled by the hypothalamic neuropeptides growth hormone releasing hormone $(\mathrm{GHRH})$ and SST. GHRH is produced in the arcuate nucleus of the hypothalamus and it represents the central stimulator and regulator of $\mathrm{GH}$ synthesis and release. SST is produced in the periventricular nucleus of the hypothalamus and it mediates the negative feedback operated by $\mathrm{GH}$ on its own release, by acting through seven transmembrane domain G-protein-coupled receptors, the SSTRs subtypes 1-5 [32]. SSTR2 has been reported to be the dominant SSTR influencing $\mathrm{GH}$ release from the somatotroph cells; the inhibition of $\mathrm{Ca}^{2+}$ influx (through L- and T-type voltage-sensitive channels), the stimulation of $\mathrm{K}^{+}$influx and the inhibition of cAMP levels have been reported to be the dominant signal transduction involved in this SSTR2 function [33]. GH action is mediated via GHR, which is widely expressed in many human tissues. GHR exists as pre-formed dimers; conformational changes induced by ligand binding activate signal transduction [34]. GH/GHR dimer interaction mainly results in the activation of different tyrosine kinases. The activation of JAK2, a protein of Janus kinase family, is thought to be the key regulator of $\mathrm{GH}$ transduction signalling. Several signalling proteins and downstream pathways are activated as a consequence of GHR/JAK2 complex formation, including STAT (signal transducers and activators of transcription) 1, 2, 3 and 5 (mainly 5a and 5b), phosphatidylinositol 3-kinases 


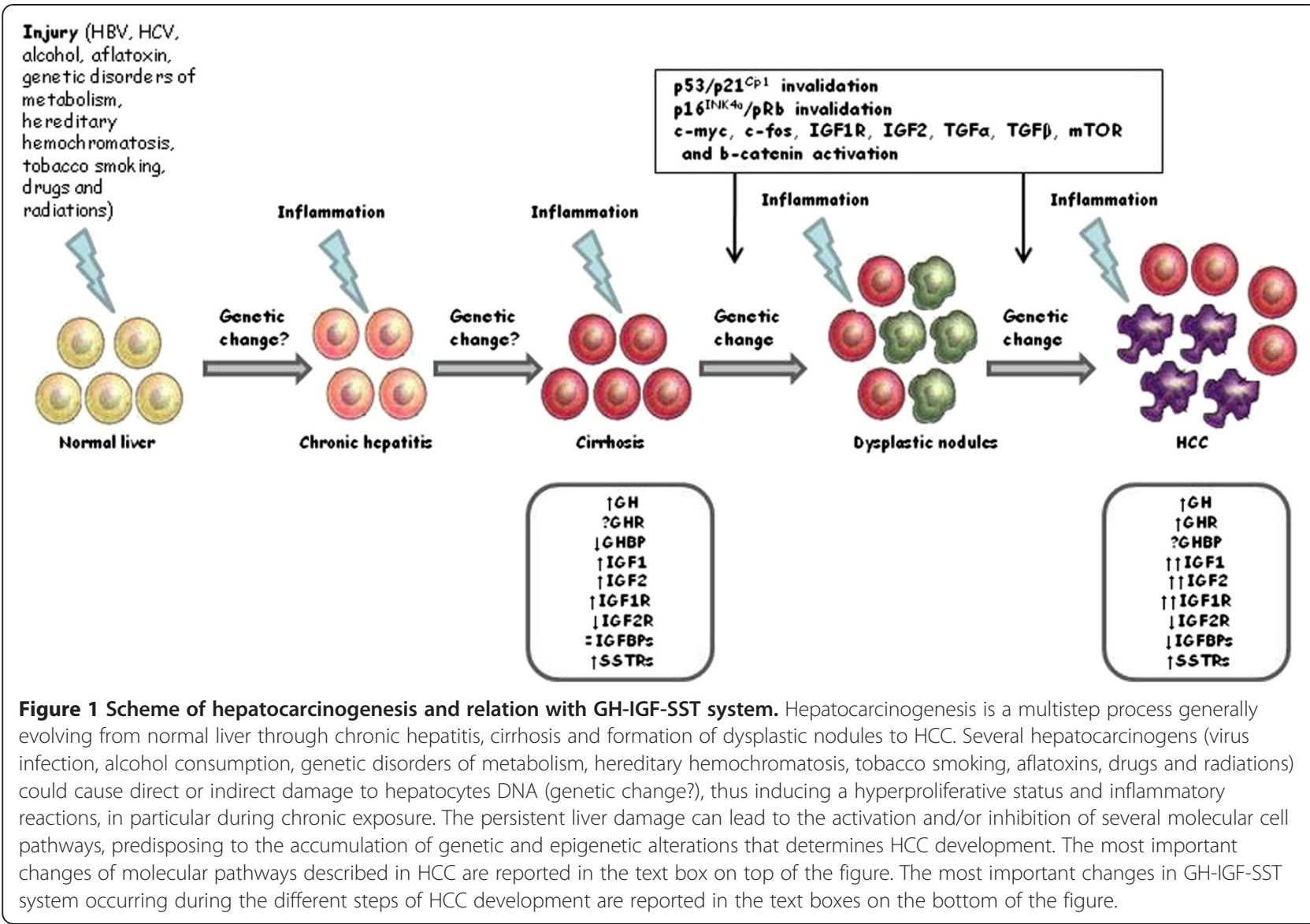

(PI3K) and mitogen-activated protein kinases (MAPKs) [34]. STAT5a and STAT5b activation is critical for some important GH functions, including the regulation of body growth and metabolism, and, in particular, the stimulation of IGF1 synthesis [35] and the regulation of the expression of crucial liver genes [30,36]. Figure 2 shows a simplified scheme of the GH-activated intracellular pathways. GHBPs are produced by a proteolytic cleavage of GHR at the site proximal to the cell surface. GHBPs bind about half of the circulating $\mathrm{GH}$ and have several and complex functions, including the modulation of plasma GH halflife and the binding of GH to GHR [37].

IGF1 plays an essential role in the body growth and metabolism, especially during the postnatal life, through the activation of IGF1R. It has been suggested that serum IGF1 postnatally supplied by the liver plays an endocrine role that is nearly as significant for the growth as the autocrine/paracrine action of IGF1 produced locally in various tissues [33]. On the other side, serum IGF1 exerts a negative feedback on GH production, by directly inhibiting the pituitary gland secretion and indirectly stimulating SST and inhibiting GHRH secretion [33]. IGF2 is a circulating peptide hormone whose regulation can be under the control of GH [38]. IGF2 plays an important role in the body growth and metabolism, especially during the prenatal life. Indeed, IGF2 is preferentially expressed during embryogenesis and foetal development, it stimulates cell growth and proliferation and it promotes embryo and fetus growth, by activating IGF1R and insulin receptor (IR), in particular the isoform A (IRA), which is predominantly expressed during prenatal life [39,40]. IGF2 can also bind to IGF2R, which is considered a "scavenger receptor". Indeed, the binding of IGF2 to this receptor assigns IGF2 to degradation towards the lysosomes and does not elicit any proliferation or survival signals $[41,42]$. Overall, IGFs may also play an autocrine or paracrine role by binding to IGF1R and/ or IR on target cells $[43,44]$. IGFs are involved in many cell processes, including cell differentiation, cell growth and proliferation, and apoptosis. These effects are predominantly mediated by the activation of two signalling cascades: MAPK and PI3K pathways. The binding of IGFs to their receptor tyrosine kinases (RTKs) triggers the phosphorylation of several substrates, including insulin receptor substrate (IRS1-4) proteins, leading to the activation of PI3K and, subsequentially, to the activation of the serine-threonine kinase (AKT) and downstream signalling effectors, including the mammalian target of 


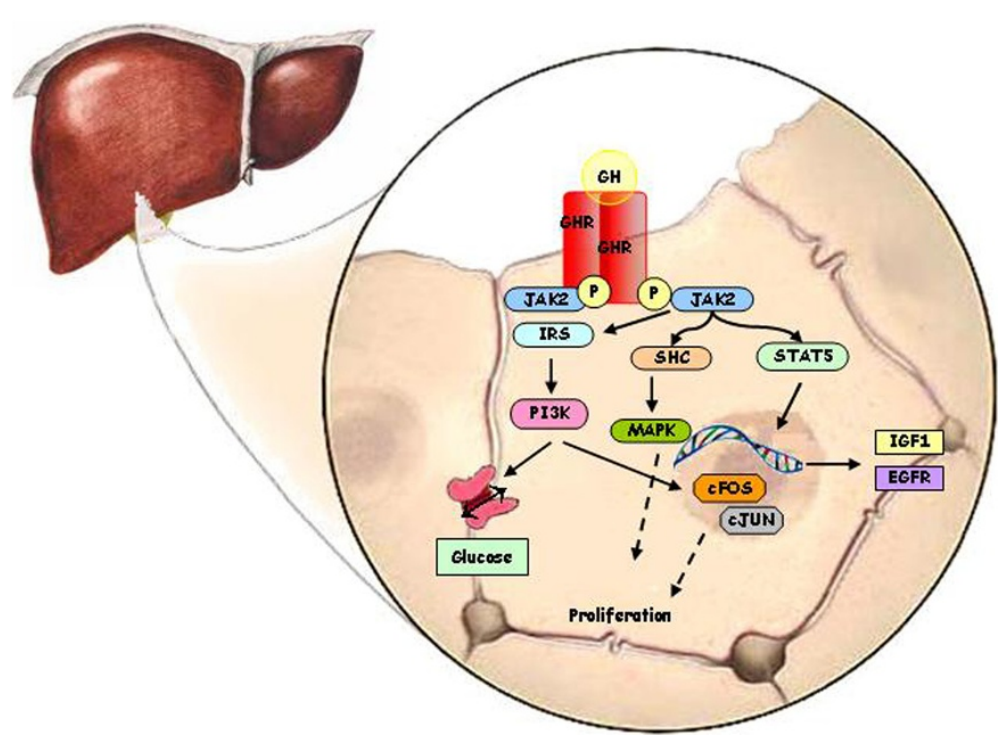

Figure 2 Intracellular pathway associated with GHR activation in hepatocytes. GH exerts its effect by binding to the extracellular domain of the GHR, where one molecule of GH binds two GHRs increasing the affinity of both receptors for two molecules of JAK2, which phosphorylate the GHR. GHR activation, in turn, triggers the activation of several signal transduction pathways, including STAT and PI3K through IRS. IRS and PI3K can activate nuclear transcription factors, including c-FOS and c-JUN, to induce cell proliferation and differentiation but also can increase glucose transport. GH-induced JAK2 activation phosphorilates STAT5 which translocates into the nucleus where binds to response elements in the regulatory regions of target genes including IGF1 and EGFR. The activation of adaptor protein SHC leads to the activation of MAPK involved in cell proliferation and growth.

rapamycin (mTOR), 4E-binding proteins (EIF4EBP1) and p70 ribosomal protein S6 kinase (RPS6KB1). In addition, IRS1 and IRS2 can activate rat sarcoma viral oncogene homolog (RAS) and, subsequentially, the MAPK pathway, including mitogen/extracellular signal-regulated kinase (MEK) and extracellular signal-regulated kinase (ERK) [44]. Figure 3 shows a simplified scheme of the IGFactivated intracellular pathways.

The IGFBP superfamily includes six proteins (IGFBP16), which are able to bind the IGFs with different affinity. IGFBP-IGF complexes influence IGFs activities by modulating their half-life and tissues bioavailability [45]. IGFBPs are produced by a variety of different tissues: IGFBP1 expression is restricted to the liver, IGFBP2 expression is predominat in tissues derived from ectoderm and endoderm, IGFBP3 and IGFBP4 are expressed in a specific subset of mesenchymal cells and IGFBP5 is expressed in tissues derived from ectoderm and muscle precursor cells [45]. IGFBPs are considered pleiotropic molecules, with IGF-dependent and IGF-independent actions. About $80 \%$ of circulating IGF1 is bound to IGFBPs, mainly to IGFBP3. IGFBP3 is the most abundant binding protein and binds IGF1 or IGF2 and the acid-labile subunit (ALS) protein, forming a ternary complex $[43,44]$. ALS is a glycoprotein that interacts with IGFBP3 only when IGFBP3 is associated to IGF1 or IGF2 $[43,44]$. This phenomenon is possible because, in normal conditions, the total IGFs and IGFBP3 are present in the serum at equimolar concentrations. To a smaller degree, IGFBP5 also forms a ternary complex with IGFs and ALS $[45,46]$. ALS increases the molecular mass of the IGF/IGFBP3 complex, by modulating the amount of IGFs that can diffuse to the extracellular fluids [45]. The other IGFBPs with low molecular mass do not form a ternary complex with any other protein, and mainly circulate associated in a binary complex with IGF1 or IGF2 $[45,46]$. IGF-independent actions of IGFBPs include effects on cell proliferation, apoptosis, motility and migration and they can be mediated by either intact IGFBPs or by their proteolysed fragments $[47,48]$. A schematic outline of GH-IGF-SST system in human adult life is represented in Figure 4.

\section{The GH-IGF-SST system: a focus on liver}

The liver is the major target organ of GH, since GH induces IGF1 expression and secretion in hepatocytes, the liver parenchymal cells and, at a lesser extent, in cholangiocytes [49]. Moreover, in hepatocytes, GH is also deputed to the regulation of glucose metabolism by reducing glucose uptake and promoting gluconeogenesis [50].

IGF1 and IGF2 have broad insulin-like actions, including promotion of energy storage and fatty acid synthesis in the liver. In mice and humans, the circulating IGF1 derives predominantly from hepatocytes [51,52]. The IGF1 derived from the liver has a central role as 


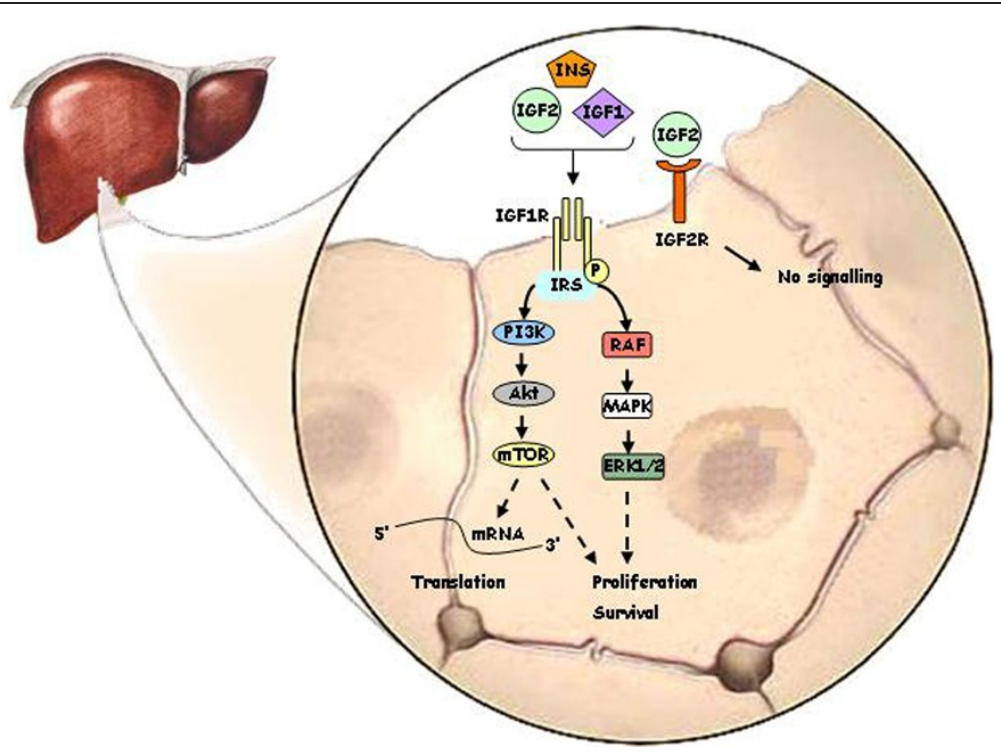

Figure 3 Intracellular pathway associated with IGF1R activation. IGF1R activation by INS, IGF1 and IGF2, leads to autophosphorylation on tyrosines 1131, 1135 and 1136 in the kinase domain, followed by recruitment of specific docking intermediates, such as members of the IRS family (IRS-1, IRS-2, IRS-3, IRS-4). This molecule link the IGF1R to diverse signalling pathways, allowing the induction of growth, transformation, differentiation and protection against apoptosis, primarily through the activation of the PI3K/Akt/mTOR and the Ras GTPase/Raf-1 (Raf)/Mek (MAPK)/Erk (ERK1/2) signalling pathways.

mediator of $\mathrm{GH}$ in the regulation of postnatal growth. Indeed, studies conducted in bitransgenic mice with IGF1 gene expression in the liver but not in extrahepatic tissues, have demonstrated that the growth rate of these mutated mice was not significantly different from wildtype animals, suggesting that IGF1 derived from the liver is important but not essential for the postnatal growth [53]. IGF1 produced in extrahepatic tissues also plays an important role as autocrine and/or paracrine regulator of postnatal growth. Indeed, studies conducted in knockout mice, with liver-specific deletion of IGF1 gene and normal IGF1 gene in extrahepatic tissues, demonstrated

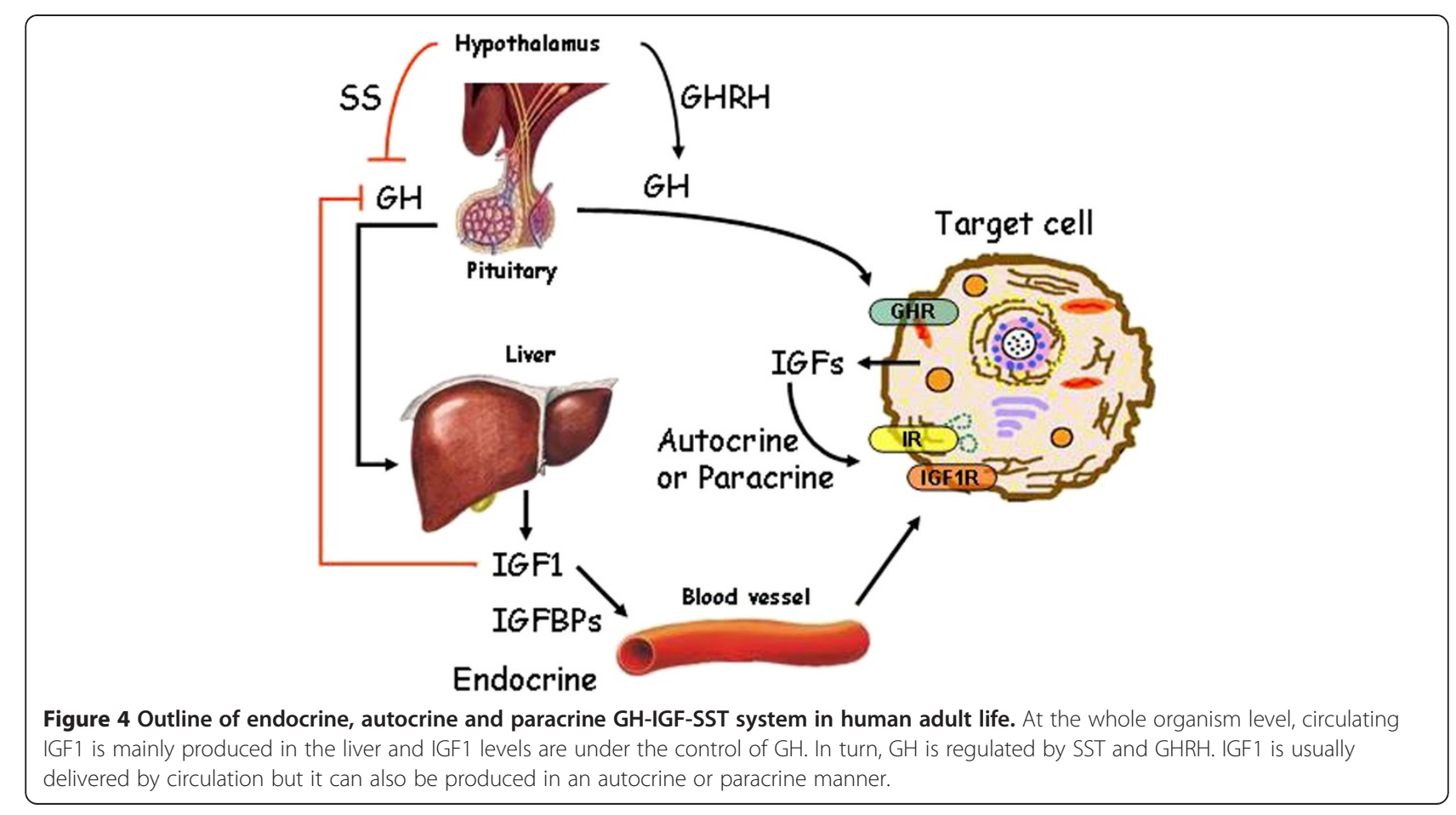


that the growth rate of these mutated mice was not significantly different from wild-type animals, thus the IGF1 produced in extrahepatic tissues is important but not essential for the postnatal growth $[54,55]$. Therefore, both IGF1 produced in the liver and IGF1 produced in extrahepatic tissues play an important role in the postnatal growth, in both an endocrine and autocrine/paracrine manner [53-55].

IGF2 expression has been demonstrated in rat hepatocytes, Kupffer cells (KCs), hepatic endothelial cells (ECs) and hepatic stellate cells (HSCs) [56,57], and in human foetal and adult hepatocytes [52,58]. IGF2 gene transcription largely varies during development, depending on the activation of distinct patterns of four different IGF2 gene promoters (P1-P4). In rodents, promoters P2, P3 and P4 are active during foetal growth in the liver, whereas, after birth, P1 becomes the dominant promoter and P2-P4 decrease their activity [59]. In humans, the transcription of IGF2 during foetal development is preferentially under the regulation of P2, P3, P4 promoters, while all promoters regulate IGF2 transcription from two months after birth onwards [58].

IGF1R has been reported to be abudantly expressed in rat KCs, ECs and HSCs, whereas its expression in rat hepatocytes is scant, suggesting that IGF1 does not have a strong autocrine/paracrine direct effect on hepatocytes in this animal model $[57,60]$. IGF2R is expressed in rat non-parenchimal liver cells [57]. No studies reported IGF1R and IGF2R expression in human normal liver. IGFBP1, IGFBP2, IGFBP4 and ALS are produced by rat hepatocytes [61-63], whereas IGFBP3 seems to be produced by rat KCs, ECs and HSC $[64,65]$. In humans, messenger and protein expression of IGFBPs has been evaluated in the liver. IGFBP1, IGFBP2 and IGFBP4 messenger and protein are widely expressed in the parenchymal cell population; IGFBP3 messenger and protein are localized in KCs $[52,66]$; IGFBP5 is produced by HSCs [67]. These binding proteins, involved in the control of the pool of bioactive IGFs, are under the control of the nutritional status and well correlate with the liver functional reserve [68]. Several studies demonstrated that insulin, glucagon and IGFs are able to regulate the transcription of IGFBPs genes [65,68,69].

No studies reported SSTRs expression in mouse or rat normal liver. SSTRs expression has been evaluated in a human normal hepatocytes cell line, the L-02, in which SSTR2 and SSTR4 messengers have been detected by molecular techniques [70]. However, SSTRs protein expression has been reported in human normal liver tissue, at the level of cholangiocytes, but not in hepatocytes $[27,71]$. The main action of SST in the liver has been explored in pre-clinical in vivo studies. In rats subjected to bile duct ligation, SST affects cholangiocytes choleretic activity, by counteracting the effect of secretin on the biliary excretion of water and bicarbonate by cholangiocytes, in cholestatic conditions [72]. Moreover, studies performed in rats have demostrated that SST has a role in the regulation of lipid metabolism [73].

\section{The GH-IGF-SST system in hepatocarcinogenesis}

A large number of studies has evaluated the role of GHIGF-SST system in the development and progression of $\mathrm{HCC}$, but results are controversial (Figure 1).

\section{$\mathrm{GH}$ and $\mathrm{GH}$ receptor}

The role of $\mathrm{GH}$ on the development and progression of $\mathrm{HCC}$ is still matter of controversies.

In a preclinical setting, the use of recombinant human growth hormone (rhGH) has been tested predominantly in in vitro studies conducted in two HCC cell lines: Bel7402 and SMMC-7721 [74]. Among these cell lines, only Bel-7402 cells were found to express GHR messenger [74]. The treatment with rhGH induced an increase of the percentage of cells in mitotic phase G2-M, as well as an increase of cell invasion and proliferation in Bel7402, but not in SMMC-772 [74]. In addition, rhGH treatment induced an overexpression of vascular endothelial growth factor (VEGF) in Bel-7402 cells, but not in SMMC-7721 [74]. Based on this preclinical study, it can be speculated that rhGH could affect $\mathrm{HCC}$ growth in GHR positive HCC, both directly and indirectly, via VEGF secretion. The binding of GH to GHR triggers the activation of intracellular signals, among which the predominant effector is Stat5 [30]. Although the activation of Stat 5 has been associated with tumourigenesis of several solid tumours [75], in the liver, Stat5 has a role as tumour promoter but it seem to have also a potential role as tumour suppressor gene [75,76]; therefore, the role of Stat 5 in hepatocarcinogenesis is still debated. Stat5b enhances HCC cell aggressiveness through the induction of epithelial-mesenchymal transition, as demonstrated in a human transfected HCC cell line [77]. In apparent contrast, loss of STAT5 in mice caused liver steatosis and fibrosis, and promoted chemically induced HCC, by up-regulating the TGF-beta (TGF- $\beta$ ) and by altering the expression of cell cycle pathway regulators $[76,78]$. Liver steatosis results from excessive synthesis of free fatty acid, whose release is regulated not only by $\mathrm{GH}$ bu also by glucocorticoids (GCs). Recently, in a study investigating the role of combined deletion of hepatic STAT5 and glucocorticoid receptor (GR) in mice, it has been observed that the block of GH and GCs signallings induces lipid accumulation in the liver, which, in turn, contributes to liver chronic inflammation with progression to cirrhosis; this condition subsequently promotes tumorigenic transformation of hepatocytes [79]. This study suggests that hepatic GH signalling is crucial for the maintenance of lipid homeostasis and that the 
impairment of this signalling causes severe metabolic liver disease predisposing to HCC.

Few studies reporting GHR expression in $\mathrm{HCC}$ are presently available in literature [80-82]. In one of these studies, GHR expression has been investigated in 40 different samples of HCC tissues: GHR was undetectable in 5 samples, whereas in the remaining 35 HCC tissues GHR was expressed but it was associated with a lower GH binding ability compared to normal liver [82], suggesting that HCC could be partially resistent to $\mathrm{GH}$ stimulation. In HCC patients undergoing hepatectomy, rhGH has been evaluated as a potential treatment to improve the protein catabolism that complicates major surgical procedures. In this study, 24 HCC patients were randomly assigned to two postoperative treatment groups: parental nutrition vs parental nutrition plus rhGH. In the last group an increase of GH-IGF1 axis (evaluated as circulating IGF1 and IGFBP3) was observed without any change in tumour-free survival rates and median tumour-free survival time [83]. Chronic liver diseases were found to be associated with increased circulating GH levels, compared with healthy subjects $[84,85]$. However, in patients with cirrhosis, despite the increase in circulating GH levels, serum IGF1, IGFBP3 and ALS levels and the IGF1 response to GH were found to be lower than in controls, resembling a condition of GH resistance, as a consequence of liver dysfunction [86].

In summary, in vitro data suggest that $\mathrm{GH}$ can stimulate human $\mathrm{HCC}$ cell proliferation but patients with HCC seem to have a condition of GH resistence that might reduce these effects in an in vivo setting Further studies are still necessary to better address the role of $\mathrm{GH}$ in hepatocarcinogenesis.

\section{IGF1 and IGF2}

The role of IGF1 and IGF2 on the development and progression of $\mathrm{HCC}$ has been widely studied.

IGF1 and IGF2 messenger expression in human HCC cell lines is reported in literature with conflicting results. Personal unpublished data seem to suggest that HepG2 and HuH-7 cell lines do not express IGF1 but largely express IGF2 [87]. The high expression of IGF2 messenger has been also reported in different studies $[88,89]$, while endogenous IGF1 messenger expression has been reported in HepG2 and HuH-7 cell lines only in one study [90].

The role of IGF1 in hepatocarcinogenesis has been explored in preclinical settings, focusing on the ability of IGF1 to regulate $\mathrm{HCV}$ infection. HCV RNA-containing viruses are present in blood as hybrid particles, termed lipoviroparticles (LVPs), composed by host lipoproteins (low-density lipoprotein [LDL] and very-low-density lipoprotein [VLDL]) and immunoglobulins. As part of these LVPs, HCV are highly able to infect host cells by binding lipoprotein receptors and escaping antibodies recognition [91]. Recently, it has been demonstrated that the lipolytic enzyme lipoprotein lipase (LPL) inhibits HCV infection by blocking virus cell entry in a HCC cell line [92]. In a human HCC cell line it has been reported that IGF1 downregulates LPL messenger expression and reduces its enzymatic activity [93]. Therefore, IGF1 could play a role in hepatocarcinogenesis by favouring $\mathrm{HCV}$ infection. In $\mathrm{HuH}-7$ and HepG2 cell lines, it has been showed that IGF2 downregulation decreases cell proliferation [94]. Additionally, it has been reported that IGF2 gene is a "carrier" for miR-483, an intronic micro-RNA (miRNA), which is able to stimulate cell proliferation in HCC, through the downregulation of its target Socs3 (suppressor of cytokine signaling 3) [95]. IGF2 has also a role in tumour cells migration and angiogenesis. Indeed, in the human HCC cell line HepG2, under conditions of hypoxia, IGF2 messenger expression has been found to be increased, and, in turn, IGF2 has been shown to stimulate VEGF cell production. Moreover, in HepG2, the silencing of IGF2 gene has been shown to reduce the secretion of VEGF in cell supernatants and to decrease the in vitro colony formation [96]. In in vivo preclinical studies, it has been reported that IGF1 messenger levels are lower in the liver tumour tissue than in the tumour-surrounding tissue or healthy liver tissue of mice harbouring HCC [97]. IGF2 messenger levels are elevated in murine HCCs with enhanced metastatic potential, as compared to murine low invasive HCCs [98]. Dysregulation of IGFs could have a role in the pathogenesis of at least a subset of HCCs. The role of IGF1 is controversial. Several studies have demonstrated that high serum IGF1 and low serum IGFBP3 are associated with an increased risk of prostate, breast, colorectal and lung cancer, and HCC [99-101], probably due to the high bioavailability of mitogenic IGF1. HCC associated with cirrhosis, regardless of $\mathrm{HBV}$ and $\mathrm{HCV}$ infection, is characterized by significantly lower levels of serum IGF1 than healthy subjects $[102,103]$. In patients with liver cirrhosis, a condition of IGF1 deficiency is thought to result from the reduced synthetic capability of damaged hepatocytes, as supported by the correlation between IGF1 levels and albumin in cirrhotic patients [104]. In HCC, the reduced binding of GH to the GHR could contribute to the IGF1 deficiency [82]. Additionally, the low circulating levels of IGF1 significantly correlate with advanced clinicopathologic parameters and poor overall survival in patients with HCC [105]. In a study evaluating IGF1 and IGFBP3 levels in 40 cirrhotic patients, 63 HCC patients and 150 healthy subjects, both serum IGF1 and IGFBP3 levels were significantly lower in cirrhotic and HCC patients than in controls. Interestingly, the IGF1/ 
IGFBP3 ratio in HCC patients was significantly higher than in both cirrhotic patients and controls, suggesting that HCC could be associated with an increased IGF1 bioavailability [101]. Therefore, it has been suggested that IGF1/IGFBP3 ratio, more than IGF1 itself, could play a role in hepatocarcinogenesis. Therefore, IGF1 bioactivity could be an attractive parameter $[100,106]$ to be investigated in patients with chronic liver disease and HCC. Conversely to IGF1, serum IGF2 levels in patients with HCC were significantly higher than in patients with cirrhosis and healthy subjects [107-109].

Regarding the expression of IGFs in human liver tissues, it has been reported that IGF1 messenger expression is lower in HCC than in normal liver, while no relevant differences have been found in liver tissues from patients with chronic hepatitis, as compared with normal liver $[110,111]$. However, IGF1 messenger expression is lower in human chirrotic tissues than in both tumour and normal liver tissues [110,112]. IGF2 messenger has been reported to be overexpressed in human liver with chronic hepatitis, cirrhosis and HCC as compared with normal adult liver [113-116]. Additionally, high IGF2 protein expression has been described in HBV- and HCV-positive HCC tissues, compared with normal and HCC cirrhotic and virus negative tissues $[117,118]$. The inactivation of adult-specific IGF2 promoter (P1) [119] and the activation of foetal-specific IGF2 promoters (P2-P4) could represent the mechanism underlying IGF2 dysregulation in HCC [120]. Indeed, in human HCC cell lines it has been shown that HBV X protein stimulates $\mathrm{P} 3$ promoter activity and $\mathrm{HCV}$ core protein is able to increase IGF2 P4 promoter expression [121,122]. Therefore, HBV and HCV infection can promote IGF2 overexpression, which is a common feature of human HCCs. IGF2 transcription is also regulated by aflatoxin $\mathrm{B} 1$, an $\mathrm{HCC}$ causative toxic compound produced by Aspergillus molds, specifically through the activation of $\mathrm{P} 4$ promoter. Indeed, aflatoxin B1 induces a mutation in p53 gene, at the level of codon 249 (p53mt249), that strongly increases the activity of P4 [123]. Furthermore, in human HCC tissues it has been demonstrated that VEGF and IGF2 gene-specific single nucleotide polymorphisms are significantly correlated to the expression of metastatic tumour antigen 1 (MTA1), a metastasis-associated protein involved in the increase of cell migration and invasion [124].

In conclusion, IGFs seem to have a role in hepatocarcinogenesis. IGF1 has a main role in influencing $\mathrm{HCV}$ infection capability, thus contributing to HCC development. Moreover, the increased IGF1 bioavailability in patients with $\mathrm{HCC}$, probably as a consequence of autocrine secretion by the neoplasm, could be an important factor for tumour progression. IGF2 is highly expressed in human $\mathrm{HCC}$, where it seems to have a stimulatory effect on tumour cell proliferation. Additionally, IGF2 can be responsible, at least partially, of $\mathrm{HBV}, \mathrm{HCV}$ and aflatoxin carcinogenic effects.

\section{IGF receptors}

The role of IGF receptors, expecially of IGF1R, on the development and progression of $\mathrm{HCC}$ has been widely studied.

The expression of IGF1R is significantly increased in $\mathrm{HCC}$ in rats [65]. A growing body of evidences suggests an increase in IGF1R expression in human cirrhotic liver, hepatoma cell lines and HCC [64,88,125-128]. In a preclinical setting, an up-regulation of IGF1R expression has been identified in Hep3B, a human hepatoma cell line transfected with p53mt249 [129], and in SNU368, a human $\mathrm{HCC}$ cell line expressing $\mathrm{HBV}$ protein $(\mathrm{HBx})$ [130]. In physiological conditions, IGF1R protein is downregulated by several miRNA [131]. miRNAs are a new class of gene expression regulators that can control cell proliferation and cancer. Particularly, several miRNAs, including miR-122, miR-21, miR-222 and miR-145, seem to play a role in viral-induced liver damage, by regulating hepatocyte infection and proliferation. Among these miRNAs, miR-122 is a liver-specific miRNA abundantly expressed in hepatocytes and known to modulate lipid metabolism, HCV replication and apoptosis [132]. Persistent expression of miR-122 has been detected during hepatic cell differentiation, while miR-122 is barely detectable in primary human HCCs [132,133]. As demonstrated in normal liver cells in physiological conditions, miR-122 has been suggested to suppress IGF1R expression, by binding to the untranslated region of the messenger, which codifies for IGF1R, thus blocking IGF1R translation. This block attenuates IGF1R/Akt signalling, resulting in an increased glycogen synthase kinase-3 beta (GSK-3 $\beta$ ) activity, that, in turn, suppresses cyclin D1 expression and cell proliferation. On the other hand, the activated GSK-3 $\beta$ maintains high levels of miR-122 via CCAAT/enhancer binding protein alpha (C/EBP $\alpha)$, which enforces IGF1R suppression [134]. In pathological conditions, in particular in response to liver insults by $\mathrm{HCV}$ infection, dysregulation of this circuit may result in uncontrolled cell proliferation and, in turn, in hepatocarcinogenesis, due to a reduction of miR-122 expression, phosphorylation of Thr222/226-C/EBP $\alpha$, an enhancement of IGF1R protein, and phosphorylation of Ser9-GSK-3 $\beta$ [134]. Surprisingly, a preclinical study showed that $\mathrm{C} / \mathrm{EBP} \alpha$ expression is also upregulated by IGF2; this finding is unexpected considering that the mitogen IGF2 should decrease the expression of tumour suppressor genes such as C/EBP $\alpha$ [135]. Thus, IGF1R play a role in a regulatory circuitry whose dysfunction may contribute to the development of HCC.

In HCC, IGF1R expression seems not to be correlated with tumour size, histological differentiation, capsular 
invasion and portal venous invasion [136]. The expression of IGF2R gene has been reported significantly reduced in human HCC tissues, compared with surrounding normal liver [137]. IGF2R loss of heterozygosity coupled with intragenic loss-of-function mutations in the remaining allele is a common event in hepatocarcinogenesis [138,139]. Mutations occurring in the IGF2 binding site of IGF2R lead to increased bioavailability of circulating IGF2, thus allowing IGF2 to activate IGF1R and IR, and to enhance cell proliferation. This molecular event may favour HCC progression [140]. Figure 3 shows the intracellular signalling induced by IGF1R and IGF2R.

In conclusion, IGF1R is overexpressed in conditions predisposing to $\mathrm{HCC}$, such as cirrhosis, as well as in HCC. IGF1R overexpression facilitates IGF2 oncogenic activity. The reduction of miR-122 expression, potentially induced by HCV infection, is an important regulatory mechanism of IGF1R overexpression, representing a relevant link between IGF pathway and viral agents, in particular $\mathrm{HCV}$, and potentially between IGF pathway and development of HCV-induced HCC.

\section{GHBP}

A decrease of circulating GHBP levels has been described in patients with cirrhosis [141,142]. An increase in GHBP levels have been reported in patients with non-alcoholic fatty liver disease (NAFLD), as compared to healthy subjects [143]. Moreover, it has been clearly demonstrated that the most severe cirrhosis have significantly decreased circulating GHBP levels [141]. A hypothesis for the increased GHBP levels in NAFLD and the reduced GHBP levels in different chronic liver diseases, including cirrhosis, might be that the two isoforms of the GHR have a different pattern of expression in different liver diseases. In fact, it has been demonstrated that a truncated form of the GHR is normally expressed at low levels compared with the full-length receptor, but shows a higher ability to generate GHBP [144-146]. Some authors demonstrated that in cirrhotic liver, the expression of the truncated form of GHR was reduced compared with the full-length isoform, and this may contribute to the lower GHBP levels found in patients wirh cirrhosis [147]. Conversely, in NAFLD, some authors have hypothesised a higher expression of the truncated form of the GHR and a higher GHBP production [143]. Another hypothesis for the increased GHBP levels in NAFLD may be a higher production rate of GHBP from adipose tissue; indeed, the abdominal fat, which is increased in patients with NAFLD, is correlated with GHBP levels [148].

To our knowledge, neither in vitro nor in vivo studies investigating the role of the GHBP in hepatocarcinogenesis have been conducted up to date.

\section{IGFBPs}

IGFBPs have high affinities for IGFs, thereby the activities of either IGF1 or IGF2 are modulated by their association with IGFBPs. This evidence suggests that IGFBPs exert a protective effect towards the IGF-induced cell proliferation, through the restriction of the availability of these ligands for binding to IGF1R. IGFBPs regulate proliferation, differentiation and apoptosis of various cell types in an IGF-dependent and -independent manner $[48,149]$. IGFBP3 is the most commonly investigated binding protein. In preclinical setting, IGFBP3 has been demonstrated to induce a significant reduction of cell proliferation and invasion, in several human HCC cell lines (HAK-1B, KIM-1, KYN-2 and HepG2), through the reduction of the bioavailability of endogenous IGF2 for cell surface receptor binding [150,151]. Moreover, IGFBP3 attenuates also the proliferative action of IGF1. Indeed, in HepG2 cell line, it has been demonstrated that, in the presence and absence of IGF1, IGFBP3 attenuated the IGF1-induced proliferation at low concentrations and completely abolished the IGF1-induced proliferation at high concentrations. These results suggest that, at least in HepG2, IGFBP3 attenuates IGF1-induced proliferation by binding IGF1 and, therefore, reducing IGF1 bioavailability to its receptor [151]. Immunohistochemical analysis of HCC tissues, which express IGFBP3, reveals abnormalities in TGF- $\beta$ and/or retinoblastoma protein ( $\mathrm{Rb}$ ) pathways. These results opened the question whether IGFBP3 may mediate growth suppression via the TGF- $\beta$ and/or Rb pathways in HCC; however, this issue needs to be further investigated [152].

The expression of IGFBP1, 2, 3 and 4 in cirrhotic liver is similar to normal liver tissues, but it is significantly downregulated in $\mathrm{HCC}$ tissues, compared with normal and cirrhotic liver [153]. In HCC patients, reduced expression of IGFBP3 has been found to be significantly correlated with tumour size, histological differentiation, capsular invasion, portal venous invasion and poor survival [150]. Promoter hypermethylation of IGFBP3 gene has been suggested as a potential mechanism for IGFBP3 downregulation in HCC [154]. IGFBP3 levels were negatively correlated with liver function measured as Child-Pugh class in patients with liver cirrhosis and, weaklier, in those with HCC, as compared with healthy subjects $[101,107]$. The estimation of serum IGF1, IGF2 and IGFBP3, together with Child-Pugh score, is more effective in predicting liver dysfunction and its severity, compared to Child-Pugh score alone [107].

In conclusion, IGFBP3 is downregulated in HCC and it is correlated with important clinical parameters. Therefore, IGFBP3 could play an indirect role in HCC development by reducing IGF1 bioavailability to its receptor, and could be a molecular target for novel therapeutic strategies in HCC patients. 


\section{Somatostatin and somatostatin receptors}

An in vitro study provided the evidence that HepG2 cell line does not produce SST but it does produce cortistatin (CST), a neuropeptide showing high structural homology with SST and binding to all SSTRs [155]. SSTRs expression has been heterogeneously demonstrated by in vitro studies in human HCC cell lines, including HepG2, HepB3, HuH-7, SMMC-7721 and Bel7402, with different findings among the various cell lines, as well as in the same cell line investigated in different studies [27,70,155-158]. However, SSTR2 expression has been homogeneously documented in the entire series of cell lines [27,70,155-158]. Immunocytochemistry analysis showed that SSTRs were located mainly intracellularly in HepG2 and HuH-7 cells $[155,158]$. It has been suggested that endogenous production of CST may be responsible for SSTRs internalisation and modification in these cell lines [155].

The expression of SSTR2 has been demonstrated in tissues of mice in which HCC was induced by treatment with diethylnitrosamine [159]. The expression of SSTRs has been largely demonstrated in both resectable and unresectable human HCC tissues [27,160-163]. SSTRs protein expression has been reported to be unrelated to tumour stage, differentiation, histological tumour type and/or underlying liver disease [164]. However, a recent study evaluating the expression of SSTR2 and SSTR5 in 76 tumour samples from patients with HBV-related operable HCC, found that, in this particular subset of patients, the mean survival time was longer in the subgroup of patients expressing high SSTR2 and SSTR5, and that, at multivariate Cox analysis, tumour expression levels of SSTR2 were an independent prognostic marker [161]. Moreover, progressive upregulation of SSTRs during the different stages of hepatocarcinogenesis has been also documented [27]. In this study, SSTRs were not expressed in hepatocytes from normal liver, whereas they were expressed in cirrhotic liver and HCC, although with variable intensity [27]. Somatostatin receptor scintigraphy with ${ }^{111}$ indium pentetreotide (Octreoscan) has been used to screen HCC patient for SSTR2 and/or SSTR5 positivity. In two different cohort of patients including 127 and 70 patients, SSTR2 positivity was registered in $48 \%$ and $35.7 \%$ of patients, respectively [165]. These data demonstrated that at least a subgroup of patients with HCC presents SSTR2 and/or SSTR5 expression. In HCC, the positivity at Octreoscan was not related with the main clinical parameters $[165,166]$. However, the role of SSTR expression in HCC tissues and of Octreoscan positivity in patients with HCC should be better addressed.

In conclusion, SSTRs are expressed in HCC cell lines as well as in cirrhotic tissues and HCC, but SSTRs expresssion seems to be not correlated with tumour stage, grading and prognosis.
Targeting GH-IGF-SST system in hepatocellular carcinoma Several approaches to GH-IGF-SST system targeting have been used as novel therapeutic strategies in HCC, and some others are currently under evaluation $[167,168]$. Generally, molecular therapeutic strategies include the use of antibodies, which can have anti-ligand and/or anti-receptor activity, the use of small molecules inhibitors, which can interfere with key enzymatic functions, and the use of synthetic receptor agonists or antagonists $[25,169,170]$. All these approaches can interfere with cell proliferation and/or, specifically, with apoptosis. Monoclonal antibodies and small molecule inhibitors can be used to target receptors, particularly growth factor-RTK. These growth factor-RTK targeting approaches can be combined with different small molecule inhibitors targeting cytoplasmic oncogenic kinases [170]. Figure 5 shows the therapeutic strategy involving GHIGF-SST system in the treatment of HCC.

\section{$\mathrm{GH}$ and $\mathrm{GH}$ receptor}

The modified GH analogue pegvisomant was the first specific GHR antagonist to be genetically engineered and produced by the pegylation of mutant GH [171]. The pegylation has the benefit to increase the half life of drugs and sterically interfere with GHR dimerization at the cell surface, which is essential for GHR activity [171]. The antitumour activity of pegvisomant has been tested in breast cancer, colorectal cancer and meningiomas [172-174]. In in vivo studies on animals, pegvisomant caused tumour shrinkage in nude mice xenografted with a human breast cancer cell line (MCF-7) and with two different human colorectal cancer cell lines (COLO 205 and HT-29); in these models a decrease of cell proliferation and the induction of apoptosis were clearly demonstrated [172,173]. Pegvisomant has been also demonstrated to significantly reduce the growth of meningioma in athymic mice xenografted with human meningioma primary cultures [174].

To the best of our knowledge, no studies have evaluated the effects of pegvisomant in preclinical or clinical models of HCC, but the GHR expression and GH effect on HCC permit to hypothesize a role of pegvisomant in this tumour.

\section{IGF pathway}

IGF pathway has been a target for the treatment of various tumours for long time. Two kinds of target therapy are usually used in clinical setting: anti-ligand and antireceptor drugs treatment. A list of the currently available agents targeting IGF pathway, evaluated in clinical trials for the treatment of HCC, is shown in Table 1.

\section{Anti-ligand approach}

MEDI-573, a human IgG2 monoclonal antibody (mAb), is one of the first monoclonal antibodies produced 


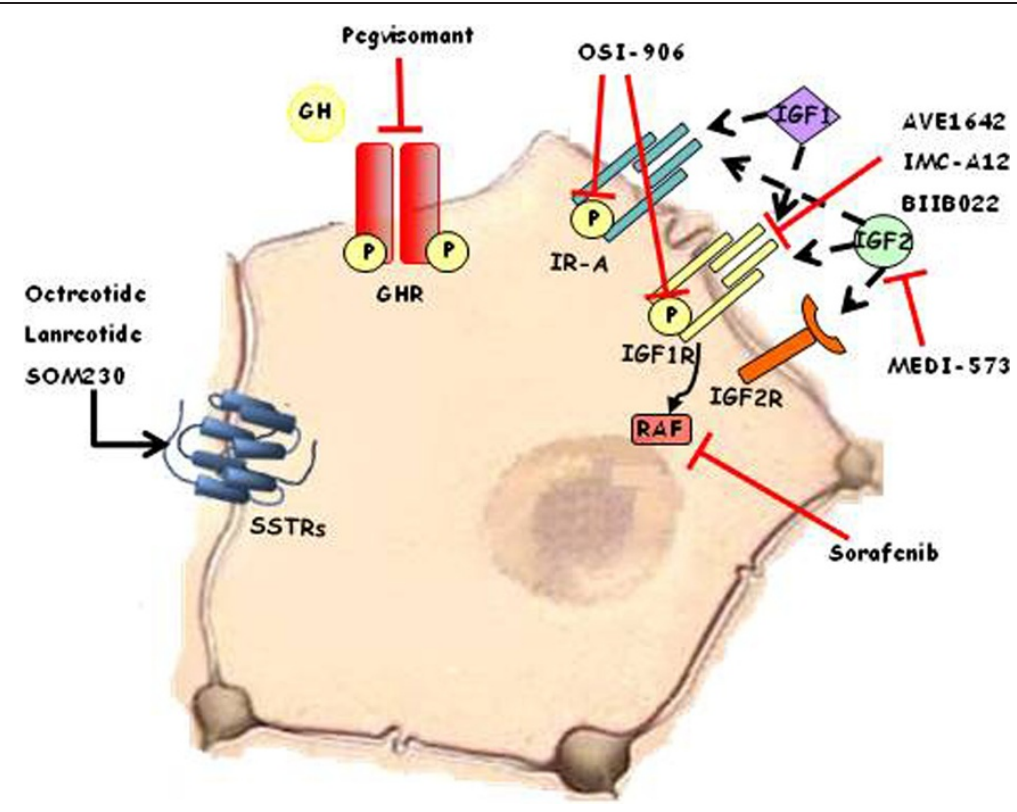

Figure 5 Several strategies in the therapeutic considerations involving GH-IGF-SST system in the treatment of HCC. Dotted black arrows: activation by endogenous ligand. Black arrow: activation by exogenous ligand. Red lines: blocking of ligands and receptors.

against ligands. This antibody neutralises both IGF1 and IGF2 without cross-reactivity to insulin. However, since it acts by neutralising IGFs, it blocks the IGF-induced activation of both IGF1R and IR downstream signalling pathways. This double effect has been confirmed by in vivo experiments in athymic mice xenografted with two mouse fibroblast cell lines: P12, engineered to overexpress human IGF1 and IGF1R proteins but not human IGF2, and C32, engineered to overexpress IGF2 and IGF1R proteins but not IGF1 [175]. Moreover, in this study, it has been demonstrated that MEDI-573 significantly inhibited the growth of P12 and C32 tumour outgrowths in xenografted nude mice [175]. To date, MEDI573 has been tested in a Phase1 study (NCT00816361) in subjects with advanced solid tumours. In a currently completed Phase1b/2 study (NCT01498952), an open-label, randomized study, MEDI-573 has been tested in combination with sorafenib, a small molecule inhibitor of several tyrosine protein kinases (VEGFR and PDGFR) and Raf kinases, in adult subjects with unresectable or metastatic

Table 1 Currently available agents against the IGF pathway evaluated in clinical trials for the treatment of HCC

\begin{tabular}{|c|c|c|c|c|c|c|}
\hline Compound & Company & Mechanism of action & $\begin{array}{c}\text { Phase of clinical } \\
\text { development }\end{array}$ & $\begin{array}{c}\text { Trial } \\
\text { Status }\end{array}$ & Intervention & Type of Cancer \\
\hline MEDI-573 & Medlmmune LLC & $\begin{array}{l}\text { Fully Human mAb anti- } \\
\text { IGF1 and -IGF2 }\end{array}$ & $1 b / 2$ & Completed & $\begin{array}{l}\text { In combination } \\
\text { with sorafenib }\end{array}$ & $\begin{array}{c}\text { Unresectable or metastatic } \\
\text { HCC }\end{array}$ \\
\hline \multirow[t]{3}{*}{ IMC-A12 } & $\begin{array}{l}\text { National Cancer } \\
\text { Institute }\end{array}$ & $\begin{array}{l}\text { Fully Recombinant } \\
\text { Human mAb anti- IGF1R }\end{array}$ & 2 & Completed & Alone & $\begin{array}{c}\text { Adult Primary, advanced, } \\
\text { localized unresectable, } \\
\text { recurrent HCC }\end{array}$ \\
\hline & $\begin{array}{l}\text { National Cancer } \\
\text { Institute }\end{array}$ & & 1 & $\begin{array}{l}\text { Active, not } \\
\text { recruiting }\end{array}$ & $\begin{array}{l}\text { In combination with } \\
\text { sorafenib tosylate }\end{array}$ & Advanced HCC \\
\hline & $\begin{array}{l}\text { Eli Lilly and } \\
\text { Company }\end{array}$ & & 2 & $\begin{array}{l}\text { Active, not } \\
\text { recruiting }\end{array}$ & $\begin{array}{l}\text { In combination } \\
\text { with sorafenib }\end{array}$ & Advanced HCC \\
\hline BIIB-022 & Biogenldec & $\begin{array}{c}\text { Human IgG4P } \\
\text { nonglycosylated } \\
\text { antibody anti-IGFIR }\end{array}$ & 16 & Completed & $\begin{array}{l}\text { In combination } \\
\text { with sorafenib }\end{array}$ & Advanced HCC \\
\hline AVE-1640 & Sanofi-Aventis & $\begin{array}{l}\text { Humanized } m A b \\
\text { anti- IGFIR }\end{array}$ & $1 / 2$ & Completed & $\begin{array}{l}\text { Alone and in combination } \\
\text { with sorafenib and erlotinib }\end{array}$ & $\begin{array}{l}\text { HCC not eligible for } \\
\text { local treatment }\end{array}$ \\
\hline OSI-906 & AstellasPharmalnc & $\begin{array}{l}\text { Small molecule } \\
\text { inhibitor of IGFIR }\end{array}$ & 2 & Completed & Alone & $\begin{array}{c}\text { With advanced HCC after } \\
\text { failure of first-line treatment } \\
\text { with sorafenib }\end{array}$ \\
\hline
\end{tabular}


HCC; however, the results of this study are not currently available.

Since IGFPB3 naturally binds the ligands of the IGF pathway, non-glycosylated human recombinant IGFBP3 (rhIGFBP3) has been proposed as ligand antagonist. In in vitro studies, rhIGFBP3 has been reported to significantly inhibit cell proliferation of murine lung metastatic (M-3LL) and human colon metastatic (LoVo) cell lines [176]. Treatment of HepG2 cells with human rhIGFBP3 led to a significant reduction in cell proliferation and attenuated the mitogenic activity of IGF1 [151].

\section{Anti-receptor approach}

IGF1R is considered the main receptor responsible for the mitogenic effects of the IGF axis [43], therefore, it represents an attractive target for anti-cancer therapy. Drugs targeting the IGF1R are also called IGF1Rblockers and include: anti IGF1R monoclonal antibodies such as CP-751,871, AVE1642/EM164, IMC-A12, SCH717454, BIIB022, AMG 479 and MK-0646/h7C10, and small molecules RTK inhibitors such as OSI-906 [43]. Several in vitro and in vivo studies have evaluated the effects of these compounds in different types of preclinical cancer models, as recently reviewed $[43,177]$. This review will focus on the studies evaluating the effects of IGF1R-blockers in HCC.

IMC-A12, also known as cixutumumab, is a fully human monoclonal IgG1 antibody that binds IGF1R with high affinity, inhibits ligand-dependent receptor activation and downstream signalling, and also mediates IGF1R internalization and degradation [178]. IMC-A12 has shown antitumoral activity against a wide range of human tumour types in in vitro studies. The effect of IMC-A12 has been evaluated in human breast (MCF7), pancreas (BxPC-3), and colon (Colo205) carcinoma cell lines, in which the antibody inhibits cell proliferation and induces cell apoptosis [179]. In the same study, IMC-A12 has also shown activity against a human tumour in both in vivo xenograft and orthotopic models. Immunohistochemical studies on tumour biopsies from mice bearing MCF7 tumours, treated with IMC-A12, showed a $20 \%$ reduction of proliferating cells and an increase of apoptotic cells [179]. IMC-A12 treatment induced significant antitumour activity also in Colo205 and BxPC-3 xenografts, affecting tumour growth and showing $>70 \%$ and $80 \%$ of growth inhibition, in Colo205 and BxPC-3 xenografts, respectively [179]. IMC-A12 has also shown potent activity, as a single agent, against xenograft models of human non-small cell and small cell lung carcinoma, as well as in models of prostate, renal, thyroid and head and neck carcinoma, multiple myeloma and sarcoma [180-183]. Nowadays, a Phase 2 study (NCT00639509) in patients with primary, advanced, localized unresectable, recurrent HCC, has been completed. The results of this study showed that
IMC-A12 did not have the expected effects in this cohort of unselected HCCs. No correlation was found between IGF1R positive staining and treatment outcome [184]. Phase 1 (NCT01008566) and Phase 2 (NCT00906373) trials with IMC-A12, in combination with sorafenib, are ongoing and the results of these studies are still awaited.

AVE1642 is a humanized version of the murine IGF1R mAb EM164. In in vitro studies in human HCC cell lines (HepG2, Hep3B, HuH-7, HuH-6, PLC/PRF5), it has been demonstrated that AVE1642 inhibits cell proliferation by preventing the activation of signalling in response to exogenous IGF1 and IGF2, but not insulin, supporting the IGF1R specifity of this antibody [88]. In the same study, it has been demonstrated that AVE1642 is able to downregulate Akt phosphorylation, and this effect was increased when AVE1642 was combined with gefitinib (EGFR inhibitor) or rapamycin (mTOR inhibitor) [88], supporting the efficacy of combined treatments in HCC. AVE1642 has been tested in a completed Phase 1/2 study (NCT00791544, as single agent and in combination with other anti-cancer therapies, in patients with advanced HCC not eligible for local treatment; the results of this study are still awaited.

OSI-906 is a potent and selective small molecule RTK inhibitor, targeting both IGF1R and IR. This drug compared with the other class of IGF1R blockers has the advantage to inhibit also the IGF2-induced IRA activation, which has been reported to favour growth in cancer [40]. OSI-906 potently inhibits ligand-dependent autophosphorilation of both IGF1R and IR, preventing the activation of pAkt, pERK1/2, and pp70S6k, and thus inhibiting cell proliferation [185]. OSI-906 displays in vitro antiproliferative effects in several human tumour cell lines and robust in vivo anti-tumour effects in IGF1R-dependent mice xenograft model of fibrosarcoma [185]. In an in vitro study, OSI-906 showed inhibitory effects on cell proliferation in several HCC cell lines, expecially in those displaying epithelial phenotype. The inhibitory effect of OSI-906 results in the inhibition of the IRS/Akt pathway [186]. Recently, a randomized, placebo-controlled, double-blind Phase 2 study (NCT01101906) has been concluded on patients with advanced HCC after failure of first-line treatment with sorafenib, but the results of this study are still awaited. Another recent Phase 2 study (NCT01334710) performed in patients with advanced HCC receiving OSI-906 in combination with sorafenib has been suspended, for safety reasons, by the pharmaceutical company. BIIB022, a human anti-IGF1R mAb, has been used in a Phase 1/b study (NCT00956436) in combination with sorafenib in patients with advanced HCC, but the results of this study are still awaited.

IGF1R-blockers have been generally documented to be well tolerated, but extended blockade of IGF1R signalling could potentially produce clinical signs and symptoms 
similar to those of severe untreated growth hormone deficiency, including visceral adiposity, dyslipidemia, deterioration of cardiac performance, osteoporosis, and impairment of physical and psychological performance $[187,188]$. Moreover, several metabolic side effects such as insulin resistance and gluconeogenesis, could result secondary to increased GH levels in the absence of IGF1R function [43].

In conclusion, preclinical studies suggest that agents targeting IGF axis could provide a promising alternative treatment in HCC patients. However, the results of clinical trials evaluating the effects of drugs targeting this axis in HCC patients are awaited.

\section{Somatostatin receptor agonists (SA)}

SSTRs are a treatment target in some types of tumours. Given the short half-life of native SST, several synthetic SA have been developed and are currently used in clinical practice, mainly to treat patients with neuroendocrine tumours (NET) [25]. Among these, the most important are: octreotide, which binds with high affinity to SSTR2 and with reduced affinity to SSTR3 and SSTR5; lanreotide, which primarily binds with high affinity to SSTR2 but shows reduced or no binding to SSTR1, 3, 4 and 5 subtypes; pasireotide, which has high affinity for SSTR5 but it also binds SSTR2, SSTR3 and SSTR1, with decrescent affinity [25,189]. Several in vitro studies using cell lines transfected with SSTRs indicate that all receptor subtypes (SSTR1-5) may mediate the inhibition of cell proliferation, whereas specific receptor subtypes (SSTR2, SSTR3) may mediate the induction of apoptosis [190]. These effects are regulated primarily via MAPK pathway and through the activation of phosphotyrosine phosphatases [191,192]. The growth inhibition effects of SA might be also induced by the restoration of functional gap junctions $[192,193]$. Moreover, SA could upregulate the tumour suppressor protein p53 and activate the pro-apoptotic member of the Bcl-2 protein family, Bax, thus triggering apoptosis [193].

In a subset of patients with NET, SA have been found to improve clinical syndrome, to control hormonal secretion and to inhibit tumour growth $[26,194,195]$. Additionally, radiolabeled-SA have been developed and are clinically used to visualize NETs or to perform radiometabolic treatments in NET patients [25]. SA, alone or in combination with other antitumour treatments, have been associated with some favourable clinical outcomes in not classical neuroendocrine solid tumours, such as prostate cancer, that has been found to express different SSTR subtypes, including SSTR2 and/or SSTR5 [26]. Therefore, it has been suggested that SSTRs might be useful also in the clinical management of patients with other types of tumours expressing SSTRs [25].
Many studies have tried to address the role of SA in HCC treatment but, up to date, both preclinical and clinical data are still controversial.

The effects of SA in both normal and tumour hepatic cells have been investigated in several in vitro studies. The activation of SSTRs results in the inhibition of proliferation in normal liver cell lines and in some, but not all, neoplastic liver cell lines [27,70,155-157,196]. Particularly, in the normal liver cell line L-02, octreotide was found to inhibit cell proliferation and, at the highest dose, it was found to induce apoptosis [70,189]. The same study also demonstrated that octreotide was able to inhibit cell proliferation and to induce apoptosis in HepG2 and SMMC-7721 HCC cell lines, which appeared to be more sensitive to the proapoptotic effects of octreotide than normal liver cell line L-02 [70]. However, these results must be considered carefully, since the drug concentration used in these in vitro experiments was higher than the maximal dose generally achieved in the therapeutic regimen of the SA, in the clinical practice [70]. The effects of octreotide on cell proliferation have been also tested in human cell lines with high (MHCC97-H) and low (MHCC97-L) metastatic potential. These cells were insensitive to the treatment with octreotide, consistently with their lack of SSTRs expression [197]. None of several subtype specific SA [L-797,591 (SSTR1 agonist), L-779,976 (SSTR2 agonist), L-796,778 (SSTR3 agonist), L-803,087 (SSTR4 agonist), and L-817,818 (SSTR5 agonist)] affected proliferation or apoptosis in two human HCC cell lines (HepG2 and HuH-7), but L-797,591 inhibited the migration of HepG2 and HuH-7 cells in the presence of chemotactic stimuli [27]. In HepG2 and HepB3 HCC cell lines, AN-238, which is a cytotoxic agent consisting of 2-pyrrolino-doxorubicin (AN-201) conjugate to a well-characterized somatostatin octapeptide carrier, RC-121 (binding SSTR2 and 5) $[198,199]$, was able to inhibit cell proliferation by inducing cell cycle block in sub-G1 phase and to induce apoptosis by triggering DNA fragmentation and cleavage of poly ADP-ribose polymerase (PARP) protein [157]. The role of the new universal SA pasireotide on HCC cell proliferation has also been recently investigated. In HepG2 cell line, treatment with pasireotide, alone or combined with celecoxib, inhibited cell viability in a dose dependent manner [200].

SA showed some antitumoral effects also in in vivo preclinical models of HCC. Treatment with octreotide inhibited tumour growth in nude mice bearing HCC xenografts [148]. Additionally, octreotide and pasireotide induced tumour necrosis, probably inhibiting VEGF expression [197,201,202]. The anti-vascular effects of SA have been supported also by in vitro and in vivo studies in experimental models of angiogenesis [203-205]. In an animal model of hepatocarcinogenesis, the effects of 
lanreotide on HCC prevention have been evaluated. In this study rats were treated chronically with a carcinogenic drug and they were assigned to three treatment groups: rats receiving lanreotide from the beginning of the experiment, rats receiving lanreotide at the onset of fibrosis, and rats not receiving lanreotide (control group). In both the groups receiving lanreotide the frequency of HCC was decreased of about $60 \%$, compared with control group. Decrease in hepatocytes proliferation and inhibition of fibrosis were also demonstrated. Additionally, when given at the start of the experiment, lanreotide dramatically decreased the levels of angiogenic factors and enhanced apoptosis [206].

Several case reports and clinical trials regarding the use of SA in the management of patients with HCC have been reported. In one of the first case reports on advanced HCC, lanreotide slow-release (lanreotide SR) was administered in order to manage para-neoplastic diarrhea. After two intramuscular injections of lanreotide SR at a dose of $30 \mathrm{mg}$ every 10 days, the alpha-fetoprotein (AFP), an important tumour marker for HCC, levels were drastically reduced and when lanreotide therapy was continued, given the good tolerance to the treatment, a slight decrease of tumour size with pronounced signs of necrotic changes were also registered [207]. The long-acting release formulation of octreotide (octreotide LAR), at a dose of $10 \mathrm{mg}$ administered monthly, has been proven to be useful in the treatment of HCC, resulting in AFP levels normalization and a complete and prolonged regression of the tumour in a patient with not resectable HCC [208]. The clinical use of octreotide LAR has been shown to be useful in a patient with metastatic HCC, in which it improved quality of life (QoL) and reduced AFP levels and tumour size [209]. Recently, lanreotide SR at the dose of $30 \mathrm{mg}$, administered twice a month, has been used to treat a patient with recurrent HCC and lung and mediastinal nodes metastases, after primary tumour complete resection. In this patient, the expression of SSTR2 was demonstrated on both primary tumour and metastases, and three months of treatment with lanreotide SR $30 \mathrm{mg}$ administered twice a month induced a decrease in the size of the mediastinal nodes and complete disappearance of the lung nodes [210]. Schematic descriptions of case reports are presented in Table 2.

Despite these positive case reports, to date several randomized and non-randomized clinical trials conducted in unresectable HCC patients using octreotide or lanreotide reported conflicting results. Several prospective non-randomized trials investigated the role of octreotide LAR or lanreotide, as summarized in Table 3. Dimitroulopoulos et al. enrolled 28 cirrhotic patients with advanced HCC. Octreoscan for the detection of SSTRs was performed in all cases. In patients showing intense uptake in the liver, octreotide was administered as follows: all patients started treatment with octreotide $0.5 \mathrm{mg}$, administered subcoutaneously every $8 \mathrm{hrs}$ for 6 weeks. After 4 weeks, treatment with ocreotide LAR $20 \mathrm{mg} / 4$ weeks was added, and between week 4 and week 6 both treatments were administered. From week 8 , patients received only octreotide LAR $20 \mathrm{mg}$ every 4 weeks, uptitrated to $30 \mathrm{mg}$ every 4 weeks from week 12. Thirteen patients unable to receive treatment were used as control group. Neither AFP reduction nor decrease of tumour mass were observed, but treatment improved both median survival time and QoL [211]. Gill et al. compared the outcomes of 22 patients with inoperable HCC treated with octreotide and $20 \mathrm{HCC}$ patients that refused treatment due to socio-economic issues (control group). Patients received octreotide $100 \mu \mathrm{g}$ subcutaneously, twice a day for 2 weeks. This treatment was followed by a monthly intramuscular administration of $20 \mathrm{mg}$ octreotide LAR. In this study octreotide LAR treatment induced tumour size regression, AFP level decrease and QoL improvement [212]. In the nonrandomized study of Samonakis et al. the survival of 32 patients with inoperable $\mathrm{HCC}$ treated with long acting SA (octreotide LAR or lanreotide SR) has been compared with a historical control group of 27 untreated patients. In these patients, the use of long acting SA appeared to have a positive effect on survival and QoL in inoperable HCC cases [213]. Plentz et al. recruited 41 patients with advanced HCC and cirrhosis, including predominantly alcoholic, and $\mathrm{HBV}$ and $\mathrm{HCV}$-induced secondarily cirrhosis, treated with short-acting and long-acting octreotide. Patients started the treatment with $50 \mathrm{mg}$ of subcutaneously administrated shortacting octreotide, 3 times a day in the first week. The octreotide dose was increased by $50 \mathrm{mg}$ per application each week until a final dose of $250 \mathrm{mg}$ octreotide, 3 times a day, was reached. After this regimen, patients received $30 \mathrm{mg}$ intramuscular octreotide LAR, once every 4 weeks. These patients were compared with a group of patients treated with transarterial chemoembolization (TACE) and no difference in median survival was registered [214]. Schoniger-Hekele et al. studied retrospectively the influence of octreotide LAR monotherapy on survival of patients with HCC and compared it to BCLC stage-matched patients who received either TACE, multimodal therapy, or palliative care only. Their study demonstrated that in the subgroup of 55 patients, classified as BCLC stage B, survival rates of patients with "active" treatments (octreotide LAR, TACE or multimodal therapy) were significantly higher than those of patients who received only palliative care. In both BCLC stage A and B patients, octreotide monotherapy showed a similar outcome, compared with patients who received TACE or multimodal therapy [215]. Slijkhuiset al. investigated the 
Table 2 Case reports of HCC treatment with SA monotherapy

\begin{tabular}{|c|c|c|c|c|c|c|}
\hline \multirow[t]{2}{*}{ Publication } & \multirow[t]{2}{*}{ Type of study } & \multicolumn{2}{|c|}{$\begin{array}{l}\text { Number of } \\
\text { enrolled patients } \\
\text { and controls }\end{array}$} & \multirow[t]{2}{*}{ Type of Cancer } & \multirow[t]{2}{*}{ SA used for treatment } & \multirow[t]{2}{*}{$\begin{array}{l}\text { Response to } \\
\text { treatment-outcome }\end{array}$} \\
\hline & & Patients & Controls & & & \\
\hline Raderer 1999 [207] & Case report & 1 & - & Advanced HCC & $\begin{array}{l}\text { LAN SR } \\
(30 \mathrm{mg} / 10 \mathrm{~d})\end{array}$ & $\downarrow A F P, \uparrow T N, S D$ \\
\hline Siveke 2003 [208] & Case report & 1 & - & Advanced HCC & $\begin{array}{l}\text { OCT LAR } \\
(10 \mathrm{mg} / 28 \mathrm{~d})\end{array}$ & $C R, \downarrow$ AFP \\
\hline Deming 2005 [209] & Case report & 1 & - & Metastatic HCC & $\begin{array}{l}\text { OCT LAR } \\
(30 \mathrm{mg})\end{array}$ & $\uparrow Q \circ L, \downarrow A F P, P R$ \\
\hline Borbath 2012 [210] & Case report & 1 & - & $\begin{array}{l}\text { Metastatic HCC with lung and } \\
\text { mediastinal nodes, HBV+, }\end{array}$ & $\begin{array}{l}\text { LAN SR } \\
(30 \mathrm{mg} / 14 \mathrm{~d})\end{array}$ & $P R$ \\
\hline
\end{tabular}

$C R$, Complete response.

$P R$, Partial response.

$Q o L$, Quality of life.

$S D$, Stable disease.

$T N$, Tumor necrosis.

$A F P$, Alpha fetoprotein.

effect of octreotide LAR in a prospective uncontrolled study. Initially, 30 patients received short-acting octreotide to ensure drug tolerability. Thereafter, 24 patients received octreotide LAR $30 \mathrm{mg}$ every 4 to 6 weeks. In this study, median time to tumour progression was 3.6 months, and median survival was 5.1 months; 7 patients (29\%) had stable disease (median duration of 8.0 months) with 2 patients demonstrating disease stability for 24 months [216]. In a study of our research group, 20 patients with advanced HCC were treated with octreotide LAR $30 \mathrm{mg} / \mathrm{month}$ and a pool of 40 patients with $\mathrm{HCC}$ with tumour staging and liver function comparable to the study patients was retrospectively selected as control. The patients treated with octreotide LAR showed a significantly higher mean survival rate, compared with controls, and patients' survival was significantly correlated with SSTR2 messenger expression in the tumour [217]. In a phase 2 multicenter study (So.LAR.), 55 patients with advanced HCC, ChildPugh A or B, received sorafenib at a dosage of $800 \mathrm{mg} /$ day for 28 days with a following week of rest and octreotide LAR at a dose of $40 \mathrm{mg}$, administered every 28 days. Treatment was well tollerated and partial response was documented in $10 \%$, whereas a stable disease was achieved in $66 \%$ of patients after treatment. This study

Table 3 Non randomized clinical trials of HCC treatment with SA monotherapy

\begin{tabular}{|c|c|c|c|c|c|c|}
\hline \multirow[t]{2}{*}{ Publication } & \multirow[t]{2}{*}{ Type of study } & \multicolumn{2}{|c|}{$\begin{array}{l}\text { Number of enrolled } \\
\text { patients and controls }\end{array}$} & \multirow[t]{2}{*}{ Type of Cancer } & \multirow[t]{2}{*}{ SA used for treatment } & \multirow[t]{2}{*}{$\begin{array}{l}\text { Response to } \\
\text { treatment-outcome }\end{array}$} \\
\hline & & Patients & Controls & & & \\
\hline Dimitroulopoulos 2002 [211] & NRCT & $15^{*}$ & $13^{\#}$ & Advanced HCC & OCT LAR (20 to 30 mg/28d) & $\uparrow S, \uparrow Q o L$ \\
\hline Gill 2005 [212] & $\mathrm{NRCT}$ & $22^{*}$ & $20^{\#}$ & Advanced HCC & OCT LAR (20 mg/28d) & $\uparrow S, \uparrow Q O L, \downarrow A F P, P R$ \\
\hline Samonakis 2002 [213] & $\mathrm{NRCT}$ & $32^{*}$ & $27^{\#}$ & Advanced HCC & NS & $\uparrow S, \uparrow Q o L$, \\
\hline Plentz 2005 [214] & $\mathrm{NRCT}$ & $41^{*}$ & $33 \cdot$ & Advanced HCC & OCT LAR (30 mg/28d) & $=\mathrm{S}$ \\
\hline \multirow[t]{3}{*}{ Schoniger-Hekele 2009 [215] } & $\mathrm{NRCT}$ & $25^{*}$ & $39+$ & Advanced HCC & OCT LAR (30 mg/28d) & $\uparrow S$ \\
\hline & & or 17• & & & & \\
\hline & & or 17. & & & & \\
\hline Slijkhuis 2005 [216] & $\mathrm{NRCT}$ & $30^{*}$ & - & Advanced HCC & OCT LAR (30 mg/28d) & SD \\
\hline
\end{tabular}

$N R C T$, Non randomized clinical trial.

AFP, Alpha fetoprotein.

$S$, Survival.

$T A C E$, Transarterial chemoembolization.

$P R$, Partial response.

$S D$, Stable disease.

$N S$, Not specified.

QoL, Quality of life.

*: treated patients.

\#: untreated patients.

$\because$ TACE treatment.

: multimodal therapy.

t: palliative. 
demonstrated that this combination of treatments can be a safe and effective option [218]. In a following study the authors investigated, in patients included in the So.LAR study, whether oxidative stress evaluated in biological samples, including both serum and peripheral blood mononuclear cells (PBMC), and pERK activation status in PBMC, could be predictive of response. The results of this study suggested that the levels of nitric oxide activity were correlated with the prognosis of HCC patients treated with So.LAR schedule and that the determination of both pERK expression in PBMC and the oxidative stress status could have a value in the prediction of response to sorafenib plus octreotide therapy in HCC patients [219].

To our knowledge, five randomized clinical trials have been performed to investigate the role of octreotide in the management of unresectable $\mathrm{HCC}$, as presented in Table 4. Kouroumalis et al. enrolled 58 patients and randomly assigned them to two groups: 28 patients received octreotide $250 \mu \mathrm{g}$ twice a day, whereas 30 patients did not receive any treatment and were considered as control group. Octreotide administration significantly improved median survival and cumulative survival rate at 6 and 12 months, as compared with control group, by decreasing AFP levels and by improving QoL after 6 months of treatment [220]. Yuen et al. performed a study with 70 patients, randomized in octreotide LAR treated group and placebo group and did not find a significant improvement in survival rate, AFP levels or QoL [221]. The value of scintigraphic uptake for predicting the therapeutic response to SA has been proven for NET [222]. Dimitroulopoulos et al. recruited 127 patients: 61 positive and 66 negative to Octreoscan. Patients positive to Octreoscan were randomized in two groups: 31 patients were treated with octreotide administered subcutaneously at the dose of $0.5 \mathrm{mg}$ every $8 \mathrm{hrs}$ for 6 weeks and then octreotide LAR at the dose of $20 \mathrm{mg}$ at the end of week 4-8; the remaining 30 patients received placebo. A significantly higher survival time and QoL were observed in the octreotide treated group, as compared with the control group and to the SSTRs negative group [166]. Becker et al. conducted a randomized, controlled trial, analyzing 119 patients, divided in 60 patients treated with octreotide LAR at the dose of $30 \mathrm{mg}$ monthly, and 59 patients treated with placebo. They observed no survival improvement and no AFP reduction in HCC patients treated with octreotide LAR, compared with patients treated with placebo [223]. Barbere et al. enrolled 272 patients randomly assigned to octreotide LAR treated group (135) and to placebo group (137). The results of this study established that octreotide does not prolong patients' survival and has a negative impact on QoL [224]. In summary, among the randomized trials, only the two Greek studies reported benefits from octreotide treatment, whereas the German, French and Chinese trials did not show any advantage from the therapy with octreotide. Because of the contradictory results of all these studies, the use of SA in the management of HCC is still matter of debate. These confliting results could depend on the heterogeneous methodology used and heterogeneous population enrolled in the study. Indeed, both the positive studies had a high proportion of HCV related HCC and a low proportion of alcoholic related HCC. Additionally, only one of the positive studies explored the effects of octreotide in a cohort of patients selected on the basis of octreoscan positivity [166]. Overall, the results of these studies demostrated that approximately $40 \%$ of HCC patients responded to SA treatment with an improvement of survival rate and an improvement of QoL, but some

Table 4 Randomized clinical trials of HCC treatment with SA monotherapy

\begin{tabular}{|c|c|c|c|c|c|c|}
\hline \multirow[t]{2}{*}{ Publication } & \multirow[t]{2}{*}{ Type of study } & \multicolumn{2}{|c|}{$\begin{array}{l}\text { Number of enrolled } \\
\text { patients and controls }\end{array}$} & \multirow[t]{2}{*}{ Type of Cancer } & \multirow[t]{2}{*}{$\begin{array}{l}\text { SA used for } \\
\text { treatment }\end{array}$} & \multirow[t]{2}{*}{$\begin{array}{l}\text { Response to } \\
\text { treatment-outcome }\end{array}$} \\
\hline & & Patients & Controls & & & \\
\hline Kourumalis 1998 [220] & $\mathrm{RCT}$ & $28^{*}$ & $30^{\#}$ & Advanced HCC & $\begin{array}{l}\text { OCT SC } \\
(500 \mu \mathrm{g} / \mathrm{d})\end{array}$ & $\downarrow A F P, \uparrow S, \uparrow Q O L$ \\
\hline Yuen 2002 [221] & $\mathrm{RCT}$ & $35^{*}$ & $35^{\circ}$ & Advanced HCC & $\begin{array}{l}\text { OCT LAR } \\
(30 \mathrm{mg} / 28 \mathrm{~d})\end{array}$ & None \\
\hline \multirow[t]{2}{*}{ Dimitroulopoulos 2007 [166] } & \multirow[t]{2}{*}{$\mathrm{RCT}$} & \multirow[t]{2}{*}{$24^{*}($ Octreoscan +$)$} & $30^{\circ}$ (Octreoscan +) & \multirow[t]{2}{*}{ Advanced HCC } & \multirow{2}{*}{$\begin{array}{l}\text { OCT LAR } \\
\text { (20 to } 30 \mathrm{mg} / 28 \mathrm{~d} \text { ) }\end{array}$} & \multirow[t]{2}{*}{$\uparrow S, \uparrow Q o L$} \\
\hline & & & $66^{\#}$ (Octreoscan -) & & & \\
\hline Becker 2007 [223] & $\mathrm{RCT}$ & $60^{*}$ & $59^{\circ}$ & Advanced HCC & $\begin{array}{l}\text { OCT LAR } \\
(30 \mathrm{mg} / 28 \mathrm{~d})\end{array}$ & None \\
\hline Barbare 2009 [224] & $\mathrm{RCT}$ & $135^{*}$ & $137^{\circ}$ & Advanced HCC & $\begin{array}{l}\text { OCT LAR } \\
(30 \mathrm{mg} / 28 \mathrm{~d})\end{array}$ & $=S, \downarrow Q o L$ \\
\hline
\end{tabular}

$R C T$, Randomized clinical trial.

$A F P$, Alpha fetoprotein.

$S$, Survival.

QoL, Quality of life.

*: treated patients.

\#: untreated patients.

:: placebo controls. 
subsets of patients, such as the Octreoscan-positive or those with HCV-related HCC, might be better candidates for this treatment. However, further studies are mandatory to better address the role of SA in the management of patients with HCC and to better explore the role of aetiology, SSTR expression, or Octreoscan positivity, as predictors of response to this treatment. Lastly, to our knowledge, no data are available regarding the use of pasireotide in patients with HCC.

In conclusion, both preclinical and clinical data suggest that SA might have antitumoural effects in a subset of HCC, further studies are required to better define the role of SA in the management of HCC patients.

\section{Conclusions}

GH-IGF-SST system seems to play a role in the development and progression of HCC, although the real impact of this system, either in physiologic or pathologic conditions, on hepatocarcinogenesis is still far from being completely understood. GH-IGF-SST system might potentially represent a target for treatment of HCC. However, drugs targeting IGF pathway and SSTRs seem to be less promising than expected, although clinical trials in selected cohorts of patients or with combined treatment could give better results. Therefore, an open challenge in this field is to define whether GH-IGF-SST system is a good target for treatment in specific subgroups of HCC patients, whether there are predictive biomarkers that can help to early identify the patients potentially responsive to this treatment, and whether combined therapy with multiple drugs targeting this pathway can be more effective than drugs used as monotherapy.

\footnotetext{
Abbreviations

AFP: alpha-fetoprotein; AKT/PKB: protein kinase B; ALS: acid-labile subunit protein; CSC: cancer stem cells; CST: cortistatin; DOX: doxorubicin;

EC: endothelial cell; EGFR: epidermal growth factor receptor; ERK: extracellular signal-regulated kinases; GC: glucocorticoid; GH: growth hormone; GHBP: growth-hormone binding protein; GHR: growth hormone receptor; GHRH: growth-hormone-releasing hormone; GR: glucocorticoidreceptors; HCC: hepatocellular carcinoma; HSC: hepatic stellate cell; HSPG: heparansulfate proteoglycans; IGF1: insulin-like growth factor 1; IGF1R: insulin-like growth factor 1 receptor; IGF2: insulin-like growth factor 2 IGF2R: insulin-like growth factor 2 receptor; IGFBP: insulin-like growth factor binding protein; INS: insulin; IR: insulin receptor; IRS: insulin receptor substrate; JAK: janus kinase protein; KC: Kupffer cell; LAR: long-acting release; LDL: low-density lipoprotein; LPL: lipoprotein lipase; LVPs: lipoviroparticles; MAPK: mitogen-activated protein kinase; MTA1: metastatic; mTOR: mammalian target of Rapamycin; NAFLD: non-alcoholic fatty liver disease; NET: neuroendocrine tumours; PARP: poly ADP-ribose polymerase; PBMC: peripheral blood mononuclear cells; PET: positron emission tomography; PI3K: phosphatidylinositol 3-Kinase; QoL: quality of life; $\mathrm{Rb}$ : retinobloastoma gene; SA: somatostatin analogue; SR: slow release; SST: somatostatin; SSTR: somatostatin receptor; STAT: signal transducers and activators of transcription; TACE: transarterial chemoembolisation; TGF: transforming growth factor; TNF: tumour necrosis factor; VEGF: vascular-endothelial growth factor; VLDL: very-low-density.
}

\section{Competing interests}

A.C. and R.P. report to receive fee as consultants to Novartis, Ipsen and Pfizer and clinical grant supports. The remaining authors do not have any relationships to disclose.

\section{Authors' contributions}

$\mathrm{CP}$ contributed to the writing of the manuscript, MN, FC, GC, Fl, AC contriduted to search the literature and to draft the manuscript, RP and MCDM contributed to the critical revision of the manuscript. All authors read and approved the final manuscript.

\section{Acknowledgements}

Dr Renata Simona Auriemma provided support of knowledge about clinical use of SA.

\section{Funding}

This study was in part supported by the grant from the Italian Ministry of Education, Research and University: FIRB RBAP11884M.

\section{Author details}

'Dipartimento di Medicina Clinica e Chirurgia, Università Federico II di Napoli, Via Sergio Pansini, 5, Naples 80131, Italy. ${ }^{2}$ IRCCS Fondazione SDN, Naples, Italy. ${ }^{3}$ National Cancer Institute G Pascale Foundation, Naples, Italy.

Received: 14 November 2012 Accepted: 23 June 2014

Published: 20 August 2014

\section{References}

1. The European Association for the Study of the Liver (EASL) and the European Organisation for Research and Treatment of Cancer (EORTC): EASL-EORTC clinical practice guidelines: management of hepatocellular carcinoma. Eur J Cancer 2012, 48(5):599-641.

2. Altekruse SF, McGlynn KA, Reichman ME: Hepatocellular carcinoma incidence, mortality, and survival trends in the United States from 1975 to 2005. J Clin Oncol 2009, 27(9):1485-1491.

3. Jemal A, Bray F, Center MM, Ferlay J, Ward E, Forman D: Global cancer statistics. CA Cancer J Clin 2011, 61(2):69-90.

4. Llovet JM, Bru C, Bruix J: Prognosis of hepatocellular carcinoma: the BCLC staging classification. Semin Liver Dis 1999, 19(3):329-338.

5. Villanueva A, Hernandez-Gea V, Llovet JM: Medical therapies for hepatocellular carcinoma: a critical view of the evidence. Nat Rev Gastroenterol Hepatol 2013, 10(1):34-42.

6. Severi $T$, van Malenstein $H$, Verslype $C$, van Pelt JF: Tumor initiation and progression in hepatocellular carcinoma: risk factors, classification, and therapeutic targets. Acta Pharmacol Sin 2010, 31(11):1409-1420.

7. Wang XW, Hussain SP, Huo TI, Wu CG, Forgues M, Hofseth L, Brechot C, Harris CC: Molecular pathogenesis of human hepatocellular carcinoma. Toxicology 2002, 181-182:43-47.

8. Merle $\mathrm{P}$, Trepo C: Molecular mechanisms underlying hepatocellular carcinoma. Viruses 2009, 1(3):852-872

9. Libbrecht L, Desmet V, Roskams T: Preneoplastic lesions in human hepatocarcinogenesis. Liver Int 2005, 25(1):16-27.

10. Wong $\mathrm{CM}, \mathrm{Ng}$ IO: Molecular pathogenesis of hepatocellular carcinoma. Liver Int 2008, 28(2):160-174.

11. Durr R, Caselmann WH: Carcinogenesis of primary liver malignancies. Langenbecks Arch Surg 2000, 385(3):154-161.

12. Villanueva A, Newell P, Chiang DY, Friedman SL, Llovet JM: Genomics and signaling pathways in hepatocellular carcinoma. Semin Liver Dis 2007, 27(1):55-76.

13. Jain $S$, Singhal $S$, Lee $P, X u$ R: Molecular genetics of hepatocellular neoplasia. Am J Transl Res 2010, 2(1):105-118.

14. Sia D, Villanueva A: Signaling pathways in hepatocellular carcinoma. Oncology 2011, 81(Suppl 1):18-23.

15. Whittaker $S$, Marais $R$, Zhu AX: The role of signaling pathways in the development and treatment of hepatocellular carcinoma. Oncogene 2010, 29(36):4989-5005.

16. Chen X, Cheung ST, So S, Fan ST, Barry C, Higgins J, Lai KM, Ji J, Dudoit S, $\mathrm{Ng}$ IO, Van De Rijn M, Botstein D, Brown PO: Gene expression patterns in human liver cancers. Mol Biol Cell 2002, 13(6):1929-1939.

17. Guichard C, Amaddeo G, Imbeaud S, Ladeiro Y, Pelletier L, Maad IB, Calderaro J, Bioulac-Sage P, Letexier M, Degos F, Clement B, Balabaud C, Chevet E, Laurent A, Couchy G, Letouze E, Calvo F, Zucman-Rossi J: I ntegrated analysis of somatic mutations and focal copy-number changes identifies key genes and pathways in hepatocellular carcinoma. Nat Genet 2012, 44(6):694-698. 
18. Boyault S, Rickman DS, de Reynies A, Balabaud C, Rebouissou S, Jeannot E, Herault A, Saric J, Belghiti J, Franco D, Bioulac-Sage P, Laurent-Puig P, Zucman-Rossi J: Transcriptome classification of HCC is related to gene alterations and to new therapeutic targets. Hepatology 2007, 45(1):42-52.

19. Renaville R, Hammadi M, Portetelle D: Role of the somatotropic axis in the mammalian metabolism. Domest Anim Endocrinol 2002, 23(1-2):351-360.

20. Gourmelen M, Perin L, Le Bouc Y: IGFs and their binding proteins. Nud Med Biol 1994, 21(3):297-302.

21. Mair M, Blaas L, Osterreicher CH, Casanova E, Eferl R: JAK-STAT signaling in hepatic fibrosis. Front Biosci 2011, 16:2794-2811.

22. Laban C, Bustin SA, Jenkins PJ: The GH-IGF-I axis and breast cancer. Trends Endocrinol Metab 2003, 14(1):28-34.

23. Rudd MF, Webb EL, Matakidou A, Sellick GS, Williams RD, Bridle H, Eisen T, Houlston RS, Consortium G: Variants in the GH-IGF axis confer susceptibility to lung cancer. Genome Res 2006, 16(6):693-701.

24. Alexia C, Fallot G, Lasfer M, Schweizer-Groyer G, Groyer A: An evaluation of the role of insulin-like growth factors (IGF) and of type-I IGF receptor signalling in hepatocarcinogenesis and in the resistance of hepatocarcinoma cells against drug-induced apoptosis. Biochem Pharmacol 2004 68(6):1003-1015.

25. De Martino MC, Hofland LJ, Lamberts SW: Somatostatin and somatostatin receptors: from basic concepts to clinical applications. Prog Brain Res 2010, 182:255-280

26. Hasskarl J, Kaufmann M, Schmid HA: Somatostatin receptors in non-neuroendocrine malignancies: the potential role of somatostatin analogs in solid tumors. Future Oncol 2011, 7(7):895-913.

27. Reynaert $\mathrm{H}$, Rombouts $\mathrm{K}$, Vandermonde A, Urbain D, Kumar U, Bioulac-Sage P, Pinzani M, Rosenbaum J, Geerts A: Expression of somatostatin receptors in normal and cirrhotic human liver and in hepatocellular carcinoma. Gut 2004, 53(8):1180-1189.

28. Samonakis DN, Notas G, Christodoulakis N, Kouroumalis EA: Mechanisms of action and resistance of somatostatin analogues for the treatment of hepatocellular carcinoma: a message not well taken. Dig Dis Sci 2008, 53(9):2359-2365.

29. Moller N, Jorgensen JO: Effects of growth hormone on glucose, lipid, and protein metabolism in human subjects. Endocr Rev 2009, 30(2):152-177.

30. Herrington J, Smit LS, Schwartz J, Carter-Su C: The role of STAT proteins in growth hormone signaling. Oncogene 2000, 19(21):2585-2597.

31. Eleswarapu S, Gu Z, Jiang H: Growth hormone regulation of insulin-like growth factor-I gene expression may be mediated by multiple distal signal transducer and activator of transcription 5 binding sites. Endocrinology 2008, 149(5):2230-2240.

32. Schneider HJ, Pagotto U, Stalla GK: Central effects of the somatotropic system. Eur J Endocrinol 2003, 149(5):377-392.

33. Tannenbaum GS, Somatostatin EJ: Hormonal Control of Growth, vol. V. In Handbook of Physiology edn. Edited by Kostyo JL, Goodman HM. 1999.

34. Lanning NJ, Carter-Su C: Recent advances in growth hormone signaling. Rev Endocr Metab Disord 2006, 7(4):225-235.

35. Woelfle J, Rotwein P: In vivo regulation of growth hormone-stimulated gene transcription by STAT5b. Am J Physiol Endocrinol Metab 2004, 286(3):E393-E401.

36. Waxman DJ, O'Connor C: Growth hormone regulation of sex-dependent liver gene expression. Mol Endocrinol 2006, 20(11):2613-2629.

37. Baumann G: Growth hormone binding protein 2001. J Pediatr Endocrinol Metab 2001, 14(4):355-375

38. von Horn H, Ekstrom C, Ellis E, Olivecrona H, Einarsson C, Tally M, Ekstrom $\mathrm{TJ}$ : GH is a regulator of IGF2 promoter-specific transcription in human liver. J Endocrinol 2002, 172(3):457-465.

39. Forbes $\mathrm{K}$, Westwood M: The IGF axis and placental function. a mini review. Horm Res 2008, 69(3):129-137

40. Belfiore A, Frasca F, Pandini G, Sciacca L, Vigneri R: Insulin receptor isoforms and insulin receptor/insulin-like growth factor receptor hybrids in physiology and disease. Endocr Rev 2009, 30(6):586-623.

41. Harris LK, Westwood M: Biology and significance of signalling pathways activated by IGF-II. Growth Factors 2012, 30(1):1-12.

42. Scott CD, Firth SM: The role of the M6P/IGF-II receptor in cancer: tumor suppression or garbage disposal? Horm Metab Res 2004, 36(5):261-271.

43. Pollak M: Insulin and insulin-like growth factor signalling in neoplasia. Nat Rev Cancer 2008, 8(12):915-928.

44. Frasca F, Pandini G, Sciacca L, Pezzino V, Squatrito S, Belfiore A, Vigneri R: The role of insulin receptors and IGF-I receptors in cancer and other diseases. Arch Physiol Biochem 2008, 114(1):23-37.
45. Clemmons DR: Insulin-like growth factor binding proteins and their role in controlling IGF actions. Cytokine Growth Factor Rev 1997, 8(1):45-62.

46. Rajaram S, Baylink DJ, Mohan S: Insulin-like growth factor-binding proteins in serum and other biological fluids: regulation and functions. Endocr Rev 1997, 18(6):801-831.

47. Clemmons DR: Role of insulin-like growth factor binding proteins in controlling IGF actions. Mo/ Cell Endocrinol 1998, 140(1-2):19-24.

48. Mohan S, Baylink DJ: IGF-binding proteins are multifunctional and act via IGF-dependent and -independent mechanisms. J Endocrinol 2002, 175(1):19-31.

49. Alvaro D, Metalli VD, Alpini G, Onori P, Franchitto A, Barbaro B, Glaser SS, Francis $\mathrm{H}$, Cantafora A, Blotta I, Attili AF, Gaudio E: The intrahepatic biliary epithelium is a target of the growth hormone/insulin-like growth factor 1 axis. J Hepatol 2005, 43(5):875-883.

50. Takahashi Y: Essential roles of growth hormone $(\mathrm{GH})$ and insulin-like growth factor-I (IGF-I) in the liver [Review]. Endocr J 2012.

51. Scott CD, Martin JL, Baxter RC: Production of insulin-like growth factor I and its binding protein by adult rat hepatocytes in primary culture. Endocrinology 1985, 116(3):1094-1101.

52. Goodyer CG, Figueiredo RM, Krackovitch S, De Souza LL, Manalo JA, Zogopoulos G: Characterization of the growth hormone receptor in human dermal fibroblasts and liver during development. Am J Physiol Endocrinol Metab 2001, 281(6):E1213-E1220.

53. Stratikopoulos E, Szabolcs M, Dragatsis I, Klinakis A, Efstratiadis A: The hormonal action of IGF1 in postnatal mouse growth. Proc Natl Acad Sci U S A 2008, 105(49):19378-19383.

54. Sjogren K, Liu JL, Blad K, Skrtic S, Vidal O, Wallenius V, LeRoith D, Tornell J, Isaksson OG, Jansson JO, Ohlsson C: Liver-derived insulin-like growth factor (IGF-I) is the principal source of IGF-I in blood but is not required for postnatal body growth in mice. Proc Natl Acad Sci U S A 1999, 96(12):7088-7092

55. Yakar S, Liu JL, Stannard B, Butler A, Accili D, Sauer B, LeRoith D: Normal growth and development in the absence of hepatic insulin-like growth factor I. Proc Natl Acad Sci U S A 1999, 96(13):7324-7329.

56. Lamas E, Zindy F, Seurin D, Guquen-Guillouzo C, Brechot C: Expression of insulin-like growth factor II and receptors for insulin-like growth factor II, insulin-like growth factor I and insulin in isolated and cultured rat hepatocytes. Hepatology 1991, 13(5):936-940.

57. Zindy F, Lamas E, Schmidt S, Kirn A, Brechot C: Expression of insulin-like growth factor II (IGF-II) and IGF-II, IGF-I and insulin receptors mRNAs in isolated non-parenchymal rat liver cells. J Hepatol 1992, 14(1):30-34.

58. Li X, Cui H, Sandstedt B, Nordlinder H, Larsson E, Ekstrom TJ: Expression levels of the insulin-like growth factor-II gene (IGF2) in the human liver: developmental relationships of the four promoters. J Endocrinol 1996, 149(1):117-124.

59. Ekstrom TJ, Cui H, Li X, Ohlsson R: Promoter-specific IGF2 imprinting status and its plasticity during human liver development. Development 1995, 121(2):309-316.

60. Caro JF, Poulos J, Ittoop O, Pories WJ, Flickinger EG, Sinha MK: Insulin-like growth factor I binding in hepatocytes from human liver, human hepatoma, and normal, regenerating, and fetal rat liver. J Clin Invest 1988, 81(4):976-981.

61. Villafuerte BC, Goldstein S, Murphy LJ, Phillips LS: Nutrition and somatomedin. XXV. Regulation of insulinlike growth factor binding protein 1 in primary cultures of normal rat hepatocytes. Diabetes 1991, 40(7):837-841.

62. Boni-Schnetzler M, Schmid C, Mary JL, Zimmerli B, Meier PJ, Zapf J, Schwander J, Froesch ER: Insulin regulates the expression of the insulin-like growth factor binding protein 2 mRNA in rat hepatocytes. Mol Endocrinol 1990, 4(9):1320-1326.

63. Menuelle $P$, Binoux M, Plas C: Regulation by insulin-like growth factor (IGF) binding proteins of IGF-II-stimulated glycogenesis in cultured fetal rat hepatocytes. Endocrinology 1995, 136(12):5305-5310.

64. Scharf JG, Knittel T, Dombrowski F, Muller L, Saile B, Braulke T, Hartmann H, Ramadori G: Characterization of the IGF axis components in isolated rat hepatic stellate cells. Hepatology 1998, 27(5):1275-1284.

65. Scharf JG, Braulke T, Hartmann H, Ramadori G: Regulation of the components of the $150 \mathrm{kDa}$ IGF binding protein complex in cocultures of rat hepatocytes and Kupffer cells by 3',5'-cyclic adenosine monophosphate. J Cell Physiol 2001, 186(3):425-436.

66. Arany E, Afford S, Strain AJ, Winwood PJ, Arthur MJ, Hill DJ: Differential cellular synthesis of insulin-like growth factor binding protein-1 (IGFBP- 
1) and IGFBP-3 within human liver. J Clin Endocrinol Metab 1994, 79(6):1871-1876.

67. Gentilini A, Feliers D, Pinzani M, Woodruff K, Abboud S: Characterization and regulation of insulin-like growth factor binding proteins in human hepatic stellate cells. J Cell Physio/ 1998, 174(2):240-250.

68. Scharf J, Ramadori G, Braulke T, Hartmann H: Synthesis of insulinlike growth factor binding proteins and of the acid-labile subunit in primary cultures of rat hepatocytes, of Kupffer cells, and in cocultures: regulation by insulin, insulinlike growth factor, and growth hormone. Hepatology 1996, 23(4):818-827.

69. Pao Cl, Farmer PK, Begovic S, Villafuerte BC, Wu GJ, Robertson DG, Phillips LS: Regulation of insulin-like growth factor-I (IGF-I) and IGF-binding protein 1 gene transcription by hormones and provision of amino acids in rat hepatocytes. Mol Endocrinol 1993, 7(12):1561-1568.

70. Liu HL, Huo L, Wang L: Octreotide inhibits proliferation and induces apoptosis of hepatocellular carcinoma cells. Acta Pharmacol Sin 2004, 25(10):1380-1386.

71. Boy C, Heusner TA, Poeppel TD, Redmann-Bischofs A, Unger N, Jentzen W Brandau W, Mann K, Antoch G, Bockisch A, Petersenn S: 68Ga-DOTATOC $\mathrm{PET} / \mathrm{CT}$ and somatostatin receptor (sst1-sst5) expression in normal human tissue: correlation of sst2 mRNA and SUVmax. Eur J Nucl Med Mol Imaging 2011, 38(7):1224-1236.

72. Tietz PS, Alpini G, Pham LD, Larusso NF: Somatostatin inhibits secretininduced ductal hypercholeresis and exocytosis by cholangiocytes. Am J Physiol 1995, 269(1 Pt 1):G110-G118.

73. Catalan RE, Martinez AM, Araones MD: Evidence for a role of somatostatin in lipid metabolism of liver and adipose tissue. Regul Pept 1984, 8(2):147-159.

74. Li S, Hou G, Wang Y, Su X, Xue L: Influence of recombinant human growth hormone ( $\mathrm{rhGH}$ ) on proliferation of hepatocellular carcinoma cells with positive and negative growth hormone receptors in vitro. Tumori 2010, 96(2):282-288.

75. Ferbeyre G, Moriggl R: The role of Stat5 transcription factors as tumor suppressors or oncogenes. Biochim Biophys Acta 2011, 1815(1):104-114.

76. Yu JH, Zhu BM, Wickre M, Riedlinger G, Chen W, Hosui A, Robinson GW, Hennighausen $\mathrm{L}$ : The transcription factors signal transducer and activator of transcription 5A (STAT5A) and STAT5B negatively regulate cell proliferation through the activation of cyclin-dependent kinase inhibitor 2b (Cdkn2b) and Cdkn1a expression. Hepatology 2010, 52(5):1808-1818.

77. Lee TK, Man K, Poon RT, Lo CM, Yuen AP, Ng IO, Ng KT, Leonard W, Fan ST: Signal transducers and activators of transcription $5 \mathrm{~b}$ activation enhances hepatocellular carcinoma aggressiveness through induction of epithelialmesenchymal transition. Cancer Res 2006, 66(20):9948-9956.

78. Hosui A, Kimura A, Yamaji D, Zhu BM, Na R, Hennighausen L: Loss of STAT5 causes liver fibrosis and cancer development through increased TGF-\{beta\} and STAT3 activation. J Exp Med 2009, 206(4):819-831.

79. Mueller KM, Kornfeld JW, Friedbichler K, Blaas L, Egger G, Esterbauer H, Hasselblatt $P$, Schlederer M, Haind $S$, Wagner KU, Engblom D, Haemmerle G, Kratky D, SexI V, Kenner L, Kozlov AV, Terracciano L, Zechner R, Schuetz G, Casanova E, Pospisilik JA, Heim MH, Moriggl R: Impairment of hepatic growth hormone and glucocorticoid receptor signaling causes steatosis and hepatocellular carcinoma in mice. Hepatology 2011, 54(4):1398-1409.

80. Garcia-Caballero T, Mertani HM, Lambert A, Gallego R, Fraga M, Pintos E, Forteza J, Chevallier M, Lobie PE, Vonderhaar BK, Beiras A, Morel G: Increased expression of growth hormone and prolactin receptors in hepatocellular carcinomas. Endocrine 2000, 12(3):265-271.

81. Wang HT, Wang J, Ou QJ, Liu XP, Chen S: [Expression of growth hormone receptor mRNA in hepatocellular carcinoma and matched para-cancer cirrhotic liver tissue]. Ai Zheng 2002, 21(2):146-148.

82. Liu JP, Wang HT, Ou QJ, Lu YT, Lu HP, Gao JH, Chu ZH, Zhao HY: [Expression of growth hormone receptor in hepatocellular carcinoma and its significance]. Ai Zheng 2003, 22(3):298-301.

83. Cao J, Luo SM, Liang L, Lai J: Effects of parenteral nutrition without and with growth hormone on growth hormone/insulin-like growth factor-1 axis after hepatectomy in hepatocellular carcinoma with liver cirrhosis. JPEN J Parenter Enteral Nutr 2007, 31(6):496-501.

84. Shankar TP, Fredi JL, Himmelstein S, Solomon SS, Duckworth WC: Elevated growth hormone levels and insulin resistance in patients with cirrhosis of the liver. Am J Med Sci 1986, 291(4):248-254.

85. Buzzelli G, Dattolo P, Pinzani M, Brocchi A, Romano S, Gentilini P: Circulating growth hormone and insulin-like growth factor-I in nonalcoholic liver cirrhosis with or without superimposed hepatocarcinoma: evidence of an altered circadian rhythm. Am J Gastroenterol 1993, 88(10):1744-1748.
86. Assy N, Pruzansky Y, Gaitini D, Shen Orr Z, Hochberg Z, Baruch Y: Growth hormone-stimulated IGF-1 generation in cirrhosis reflects hepatocellular dysfunction. J Hepatol 2008, 49(1):34-42.

87. Pivonello CNM, De Martino MC, de Angelis C, Napolitano M, Izzo F, Colao C, Hofland LJ, Pivonello R: Targeting the insulin-like growth factor 1 (IGF1R) and insulin (IR) receptors with a dual IGF1R/IR inhibitor, OSI-906, to potentiate $\mathrm{mTOR}$ inhibitor effects in experimental models of hepatocellular carcinoma (HCC). In European Congress of Endocrinology. Wroclaw, Poland; 2014.

88. Desbois-Mouthon C, Baron A, Blivet-Van Eggelpoel MJ, Fartoux L, Venot C, Bladt F, Housset C, Rosmorduc O: Insulin-like growth factor-1 receptor inhibition induces a resistance mechanism via the epidermal growth factor receptor/HER3/AKT signaling pathway: rational basis for cotargeting insulin-like growth factor-1 receptor and epidermal growth factor receptor in hepatocellular carcinoma. Clin Cancer Res 2009, 15(17):5445-5456.

89. Yao X, Hu JF, Daniels M, Shiran H, Zhou X, Yan H, Lu H, Zeng Z, Wang Q, Li T, Hoffman AR: A methylated oligonucleotide inhibits IGF2 expression and enhances survival in a model of hepatocellular carcinoma. $J$ Clin Invest 2003, 111(2):265-273

90. Hung TM, Ho CM, Liu YC, Lee JL, Liao YR, Wu YM, Ho MC, Chen CH, Lai HS, Lee PH: Up-Regulation of MicroRNA-190b Plays a Role for Decreased IGF-1 That Induces Insulin Resistance in Human Hepatocellular Carcinoma. Plos One 2014, 9(2)

91. Nielsen SU, Bassendine MF, Burt AD, Martin C, Pumeechockchai W, Toms GL: Association between hepatitis $C$ virus and very-low-density lipoprotein (VLDL)/LDL analyzed in iodixanol density gradients. J Virol 2006, 80(5):2418-2428

92. Maillard P, Walic M, Meuleman P, Roohvand F, Huby T, Le Goff W, Leroux-Roels G, Pecheur El, Budkowska A: Lipoprotein lipase inhibits hepatitis C virus (HCV) infection by blocking virus cell entry. Plos One 2011, 6(10):e26637.

93. Sukhanov SVC, Higashi Y, Titterington J, Delafontaine P: Insulin-like growth factor I (IGF-1) downregulates lipoprotein lipase and suppresses atherosclerotic foam cell formation in vivo and in vitro. Faseb J 2009, Meeting Abstract Supplement(23):593.591.

94. Lin SB, Hsieh SH, Hsu HL, Lai MY, Kan LS, Au LC: Antisense oligodeoxynucleotides of IGF-II selectively inhibit growth of human hepatoma cells overproducing IGF-II. J Biochem 1997, 122(4):717-722

95. Ma N, Li F, Li D, Hui Y, Wang X, Qiao Y, Zhang Y, Xiang Y, Zhou J, Zhou L, Zheng $X$, Gao X: Igf2-derived intronic miR-483 promotes mouse hepatocellular carcinoma cell proliferation. Mol Cell Biochem 2012, 361(1-2):337-343.

96. Yao N, Yao D, Wang L, Dong Z, Wu W, Qiu L, Yan X, Yu D, Chen J, Sai W, Zhang $H$, Yang J: Inhibition of autocrine IGF-II on effect of human HepG2 cell proliferation and angiogenesis factor expression. Tumour biology: the journal of the International Society for Oncodevelopmental Biology and Medicine 2012, 33(5):1767-1776.

97. Zinevich LS, Mikaelyan AS: Igf1 expression in mouse model of liver carcinogenesis. Dokl Biochem Biophys 2012, 442:1-3.

98. Lewis BC, Klimstra DS, Socci ND, Xu S, Koutcher JA, Varmus HE: The absence of $\mathrm{p} 53$ promotes metastasis in a novel somatic mouse model for hepatocellular carcinoma. Mol Cell Biol 2005, 25(4):1228-1237.

99. Renehan AG, Zwahlen M, Minder C, O'Dwyer ST, Shalet SM, Egger M: Insulin-like growth factor (IGF)-I, IGF binding protein-3, and cancer risk: systematic review and meta-regression analysis. Lancet 2004, 363(9418):1346-1353.

100. Vitale G, Brugts MP, Ogliari G, Castaldi D, Fatti LM, Varewijck AJ, Lamberts SW, Monti D, Bucci L, Cevenini E, Cavagnini F, Franceschi C, Hofland Lل, Mari $D$, Janssen J: Low circulating IGF-I bioactivity is associated with human longevity: findings in centenarians' offspring. Aging (Albany NY) 2012, 4(9):580-589

101. Mattera D, Capuano G, Colao A, Pivonello R, Manguso F, Puzziello A, D'Agostino L: Increased IGF-I : IGFBP-3 ratio in patients with hepatocellular carcinoma. Clin Endocrinol (Oxf) 2003, 59(6):699-706.

102. Nikolic JA, Todorovic V, Bozic M, Tosic L, Bulajic M, Alempijevic T, Nedic O, Masnikosa R: Serum insulin-like growth factor (IGF)-II is more closely associated with liver dysfunction than is IGF-I in patients with cirrhosis. Clin Chim Acta 2000, 294(1-2):169-177.

103. Stuver SO, Kuper H, Tzonou A, Lagiou P, Spanos E, Hsieh CC, Mantzoros C, Trichopoulos D: Insulin-like growth factor 1 in hepatocellular carcinoma and metastatic liver cancer in men. Int J Cancer 2000, 87(1):118-121.

104. Colakoglu O, Taskiran B, Colakoglu G, Kizildag S, Ari Ozcan F, Unsal B: Serum insulin like growth factor-1 (IGF-1) and insulin like growth factor binding 
protein-3 (IGFBP-3) levels in liver cirrhosis. Turk J Gastroenterol 2007, 18(4):245-249.

105. Kaseb AO, Morris JS, Hassan MM, Siddiqui AM, Lin E, Xiao L, Abdalla EK, Vauthey JN, Aloia TA, Krishnan S, Abbruzzese JL: Clinical and prognostic implications of plasma insulin-like growth factor-1 and vascular endothelial growth factor in patients with hepatocellular carcinoma. J Clin Oncol 2011, 29(29):3892-3899.

106. Janssen JA: Insulin-like growth factor I: pros and cons of a bioassay. Horm Res Paediatr 2011, 76(Suppl 1):106-110.

107. Rehem RNAMA, El-Shikh WMHM: Serum IGF-1, IGF-2 and IGFBP-3 as Parameters in the Assessment of Liver Dysfunction in Patients with Hepatic Cirrhosis and in the Diagnosis of Hepatocellular Carcinoma. Hepatogastroenterology 2011, 58(107):949-954.

108. Morace C, Cucunato M, Bellerone R, De Caro G, Crino S, Fortiguerra A, Spadaro F, Zirilli A, Alibrandi A, Consolo P, Luigiano C, Resta ML, Ferrau O, Spadaro A: Insulin-like growth factor-II is a useful marker to detect hepatocellular carcinoma? Eur J Intern Med 2012, 23(6):e157-e161.

109. Dong ZZ, Yao DF, Yao DB, Wu XH, Wu W, Qiu LW, Jiang DR, Zhu JH, Meng $X Y$ : Expression and alteration of insulin-like growth factor IImessenger RNA in hepatoma tissues and peripheral blood of patients with hepatocellular carcinoma. World J Gastroenterol 2005, 11(30):4655-4660.

110. Su TS, Liu WY, Han SH, Jansen M, Yang-Fen TL, P'Eng FK, Chou CK: Transcripts of the insulin-like growth factors I and II in human hepatoma. Cancer Res 1989, 49(7):1773-1777.

111. Stefano JT, Correa-Giannella ML, Ribeiro CM, Alves VA, Massarollo PC Machado MC, Giannella-Neto D: Increased hepatic expression of insulinlike growth factor-I receptor in chronic hepatitis C. World J Gastroenterol 2006, 12(24):3821-3828.

112. Luo SM, Tan WM, Deng WX, Zhuang SM, Luo JW: Expression of albumin, IGF-1, IGFBP-3 in tumor tissues and adjacent non-tumor tissues of hepatocellular carcinoma patients with cirrhosis. World J Gastroenterol 2005, 11(27):4272-4276.

113. Cariani E, Lasserre C, Seurin D, Hamelin B, Kemeny F, Franco D, Czech MP, Ullrich A, Brechot C: Differential expression of insulin-like growth factor II mRNA in human primary liver cancers, benign liver tumors, and liver cirrhosis. Cancer Res 1988, 48(23):6844-6849.

114. Sohda T, Yun K, Iwata K, Soejima H, Okumura M: Increased expression of insulin-like growth factor 2 in hepatocellular carcinoma is primarily regulated at the transcriptional level. Lab Invest 1996, 75(3):307-311.

115. Su Q, Liu YF, Zhang JF, Zhang SX, Li DF, Yang JJ: Expression of insulin-like growth factor II in hepatitis B, cirrhosis and hepatocellular carcinoma: its relationship with hepatitis B virus antigen expression. Hepatology 1994, 20(4 Pt 1):788-799.

116. Sedlaczek N, Hasilik A, Neuhaus P, Schuppan D, Herbst H: Focal overexpression of insulin-like growth factor 2 by hepatocytes and cholangiocytes in viral liver cirrhosis. Br J Cancer 2003, 88(5):733-739.

117. d'Arville CN, Nouri-Aria KT, Johnson P, Williams R: Regulation of insulin-like growth factor II gene expression by hepatitis B virus in hepatocellular carcinoma. Hepatology 1991, 13(2):310-315.

118. Nardone G, Romano M, Calabro A, Pedone PV, de Sio I, Persico M, Budillon G, Bruni CB, Riccio A, Zarrilli R: Activation of fetal promoters of insulinlike growth factors II gene in hepatitis $C$ virus-related chronic hepatitis, cirrhosis, and hepatocellular carcinoma. Hepatology 1996 23(6):1304-1312.

119. Li X, Nong Z, Ekstrom C, Larsson E, Nordlinder H, Hofmann WJ, Trautwein C, Odenthal M, Dienes HP, Ekstrom TJ, Schirmacher P: Disrupted IGF2 promoter control by silencing of promoter P1 in human hepatocellular carcinoma. Cancer Res 1997, 57(10):2048-2054.

120. Uchida K, Kondo M, Takeda S, Osada H, Takahashi T, Nakao A: Altered transcriptional regulation of the insulin-like growth factor 2 gene in human hepatocellular carcinoma. Mol Carcinog 1997, 18(4):193-198.

121. Tang SH, Hu W, Hu JJ, Wu SL, Li JF, Luo YH, Cao MR, Zhou HK, Jiang XW: Hepatitis $B$ virus $X$ protein promotes $P 3$ transcript expression of the insulin-like growth factor 2 (IGF2) gene via inducing hypomethylation of P3 promoter in hepatocellular carcinoma. Liver Int 2014

122. Lee S, Park U, Lee Yl: Hepatitis C virus core protein transactivates insulin-like growth factor II gene transcription through acting concurrently on Egr1 and Sp1 sites. Virology 2001, 283(2):167-177.

123. Lee YI, Lee S, Das GC, Park US, Park SM: Activation of the insulin-like growth factor II transcription by aflatoxin B1 induced p53 mutant 249 is caused by activation of transcription complexes; implications for a gain-of-function during the formation of hepatocellular carcinoma. Oncogene 2000, 19(33):3717-3726.

124. Lee SH, Chung YH, Kim JA, Lee D, Jin YJ, Shim JH, Jang MK, Cho EY, Shin ES, Lee JE, Park NH, Yu E, Lee YJ: Single nucleotide polymorphisms associated with metastatic tumour antigen 1 overexpression in patients with hepatocellular carcinoma. Liver Int 2012, 32(3):457-466.

125. Tsai TF, Yauk YK, Chou CK, Ting LP, Chang C, Hu CP, Han SH, Su TS: Evidence of autocrine regulation in human hepatoma cell lines. Biochem Biophys Res Commun 1988, 153(1):39-45

126. Verspohl EJ, Maddux BA, Goldfine ID: Insulin and insulin-like growth factor I regulate the same biological functions in HEP-G2 cells via their own specific receptors. J Clin Endocrinol Metab 1988, 67(1):169-174.

127. Nussbaum T, Samarin J, Ehemann V, Bissinger M, Ryschich E, Khamidjanov A, Yu X, Gretz N, Schirmacher P, Breuhahn K: Autocrine insulin-like growth factor-II stimulation of tumor cell migration is a progression step in human hepatocarcinogenesis. Hepatology 2008, 48(1):146-156.

128. Tovar V, Alsinet C, Villanueva A, Hoshida Y, Chiang DY, Sole M, Thung S, Moyano S, Toffanin S, Minguez B, Cabellos L, Peix J, Schwartz M, Mazzaferro $\checkmark$, Bruix J, Llovet JM: IGF activation in a molecular subclass of hepatocellular carcinoma and pre-clinical efficacy of IGF-1R blockage. J Hepatol 2010, 52(4):550-559.

129. Lee YI, Han YJ, Lee SY, Park SK, Park YJ, Moon HB, Shin JH, Lee JH: Activation of insulin-like growth factor II signaling by mutant type p53: physiological implications for potentiation of IGF-II signaling by p53 mutant 249. Mol Cell Endocrinol 2003, 203(1-2):51-63.

130. Kim SO, Park JG, Lee Yl: Increased expression of the insulin-like growth factor I (IGF-I) receptor gene in hepatocellular carcinoma cell lines: implications of IGF-I receptor gene activation by hepatitis $B$ virus $X$ gene product. Cancer Res 1996, 56(16):3831-3836.

131. Law PT, Ching AK, Chan AW, Wong QW, Wong CK, To KF, Wong N: MiR-145 modulates multiple components of the insulin-like growth factor pathway in hepatocellular carcinoma. Carcinogenesis 2012, 33(6):1134-1141.

132. Tsai WC, Hsu PW, Lai TC, Chau GY, Lin CW, Chen CM, Lin CD, Liao YL, Wang JL, Chau YP, Hsu MT, Hsiao M, Huang HD, Tsou AP: MicroRNA-122, a tumor suppressor microRNA that regulates intrahepatic metastasis of hepatocellular carcinoma. Hepatology 2009, 49(5):1571-1582.

133. Bai S, Nasser MW, Wang B, Hsu SH, Datta J, Kutay H, Yadav A, Nuovo G, Kumar P, Ghoshal K: MicroRNA-122 inhibits tumorigenic properties of hepatocellular carcinoma cells and sensitizes these cells to sorafenib. J Biol Chem 2009, 284(46):32015-32027.

134. Zeng C, Wang R, Li D, Lin XJ, Wei QK, Yuan Y, Wang Q, Chen W, Zhuang SM: A novel GSK-3 beta-C/EBP alpha-miR-122-insulin-like growth factor 1 receptor regulatory circuitry in human hepatocellular carcinoma. Hepatology 2010, 52(5):1702-1712.

135. Tomizawa M, Saisho H: Insulin-like growth factor (IGF)-II regulates CCAAT/ enhancer binding protein alpha expression via phosphatidyl-inositol 3 kinase in human hepatoblastoma cell lines. J Cell Biochem 2007, 102(1):161-170.

136. Dong ZZ, Yao M, Oian J, Yan XD, Chen J, Yan MJ, Yao NH, Yao DF: [Abnormal expression of insulin-like growth factor-II and intervening of its mRNA transcription in the promotion of HepG2 cell apoptosis]. Zhonghua Yi Xue Za Zhi 2013, 93(12):892-896.

137. Sue SR, Chari RS, Kong FM, Mills JJ, Fine RL, Jirtle RL, Meyers WC: Transforming growth factor-beta receptors and mannose 6-phosphate/ insulin-like growth factor-II receptor expression in human hepatocellular carcinoma. Ann Surg 1995, 222(2):171-178.

138. De Souza AT, Hankins GR, Washington MK, Fine RL, Orton TC, Jirtle RL: Frequent loss of heterozygosity on $6 q$ at the mannose 6-phosphate/ insulin-like growth factor II receptor locus in human hepatocellular tumors. Oncogene 1995, 10(9):1725-1729.

139. De Souza AT, Hankins GR, Washington MK, Orton TC, Jirtle RL: M6P/IGF2R gene is mutated in human hepatocellular carcinomas with loss of heterozygosity. Nat Genet 1995, 11(4):447-449.

140. De Souza AT, Yamada T, Mills JJ, Jirtle RL: Imprinted genes in liver carcinogenesis. FASEB J 1997, 11(1):60-67.

141. Donaghy AJ, Delhanty PJ, Ho KK, Williams R, Baxter RC: Regulation of the growth hormone receptor/binding protein, insulin-like growth factor ternary complex system in human cirrhosis. J Hepatol 2002, 36(6):751-758.

142. Baruch Y, Amit T, Hertz P, Enat R, Youdim MB, Hochberg Z: Decreased serum growth hormone-binding protein in patients with liver cirrhosis. J Clin Endocrinol Metab 1991, 73(4):777-780. 
143. Fusco A, Miele L, D'Uonnolo A, Forgione A, Riccardi L, Cefalo C, Barini A, Bianchi A, Giampietro A, Cimino V, Landolfi R, Grieco A, De Marinis L: Nonalcoholic fatty liver disease is associated with increased GHBP and reduced GH/IGF-I levels. Clin Endocrinol (Oxf) 2012, 77(4):531-536.

144. Dastot F, Sobrier ML, Duquesnoy P, Duriez B, Goossens M, Amselem S: Alternatively spliced forms in the cytoplasmic domain of the human growth hormone $(\mathrm{GH})$ receptor regulate its ability to generate a soluble GH-binding protein. Proc Natl Acad Sci U S A 1996, 93(20):10723-10728.

145. Dastot F, Duquesnoy P, Sobrier ML, Goossens M, Amselem S: Evolutionary divergence of the truncated growth hormone receptor isoform in its ability to generate a soluble growth hormone binding protein. $\mathrm{Mol}$ Cell Endocrinol 1998, 137(1):79-84.

146. Ross RJ, Esposito N, Shen XY, Von Laue S, Chew SL, Dobson PR, Postel-Vinay $M C$, Finidori J: A short isoform of the human growth hormone receptor functions as a dominant negative inhibitor of the full-length receptor and generates large amounts of binding protein. Mol Endocrinol 1997, 11(3):265-273

147. Shen XY, Holt RI, Miell JP, Justice S, Portmann B, Postel-Vinay MC, Ross RJ: Cirrhotic liver expresses low levels of the full-length and truncated growth hormone receptors. J Clin Endocrinol Metab 1998, 83(7):2532-2538

148. Nam SY, Kim KR, Song YD, Lim SK, Lee HC, Huh KB: GH-binding protein in obese men with varying glucose tolerance: relationship to body fat distribution, insulin secretion and the GH-IGF-I axis. Eur J Endocrinol 1999, 140(2):159-163.

149. Fang P, Hwa V, Rosenfeld R: IGFBPs and cancer. Novartis Found Symp 2004, 262:215-230. discussion 230-214, 265-218.

150. Aishima S, Basaki Y, Oda Y, Kuroda Y, Nishihara Y, Taguchi K, Taketomi A, Maehara Y, Hosoi F, Maruyama Y, Fotovati A, Oie S, Ono M, Ueno T, Sata M, Yano H, Kojiro M, Kuwano M, Tsuneyoshi M: High expression of insulin-like growth factor binding protein-3 is correlated with lower portal invasion and better prognosis in human hepatocellular carcinoma. Cancer Sci 2006, 97(11):1182-1190.

151. Huynh H, Chow PK, Ooi LL, Soo KC: A possible role for insulin-like growth factor-binding protein-3 autocrine/paracrine loops in controlling hepatocellular carcinoma cell proliferation. Cell Growth Differ 2002, 13(3):115-122

152. Yumoto E, Nakatsukasa H, Hanafusa T, Yumoto $Y$, Nouso K, Matsumoto E, Onishi T, Takuma Y, Tanaka H, Fujikawa T, Suzuki M, Uemura M, Shiratori Y: IGFBP-3 expression in hepatocellular carcinoma involves abnormalities in TGF-beta and/or Rb signaling pathways. Int J Oncol 2005, 27(5):1223-1230.

153. Gong Y, Cui L, Minuk GY: The expression of insulin-like growth factor binding proteins in human hepatocellular carcinoma. Mol Cell Biochem 2000, 207(1-2):101-104.

154. Hanafusa T, Yumoto $Y$, Nouso K, Nakatsukasa H, Onishi T, Fujikawa T, Taniyama M, Nakamura S, Uemura M, Takuma Y, Yumoto E, Higashi T, Tsuj $\mathrm{T}$ : Reduced expression of insulin-like growth factor binding protein-3 and its promoter hypermethylation in human hepatocellular carcinoma. Cancer Lett 2002, 176(2):149-158.

155. Notas G, Kolios G, Mastrodimou N, Kampa M, Vasilaki A, Xidakis C, Castanas E, Thermos K, Kouroumalis E: Cortistatin production by HepG2 human hepatocellular carcinoma cell line and distribution of somatostatin receptors. J Hepatol 2004, 40(5):792-798.

156. Hua YP, Yin XY, Peng BG, Li SQ, Lai JM, Liang HZ, Liang L: Mechanisms and influence of octreotide-induced regulation of somatostatin receptor 2 on hepatocellular carcinoma. Chemotherapy 2009, 55(5):312-320.

157. Lasfer M, Vadrot N, Schally AV, Nagy A, Halmos G, Pessayre D, Feldmann G, Reyl-Desmars FJ: Potent induction of apoptosis in human hepatoma cell lines by targeted cytotoxic somatostatin analogue AN-238. J Hepatol 2005, 42(2):230-237.

158. Pivonello C, Vitale G, Izzo F, Di Sarno A, Giorgio A, Hofland LJ, Colao A, Pivonello R: Hepatocellular carcinoma (HCC) as a neuroendocrine tumor: a preliminar molecular study [abstract]. In Endocrine Abstracts. 2012:781.

159. Abdel-Hamid NM, Mohafez OM, Zakaria S, Thabet K: Hepatic somatostatin receptor 2 expression during premalignant stages of hepatocellular carcinoma. Tumour biology: the journal of the International Society for Oncodevelopmental Biology and Medicine 2014, 35(3):2497-2502.

160. Verhoef $\mathrm{C}$, van Dekken $\mathrm{H}$, Hofland LJ, Zondervan $\mathrm{PE}$, de Wilt JH, van Marion $\mathrm{R}$, de Man RA, IJzermans JN, van Eijck CH: Somatostatin receptor in human hepatocellular carcinomas: biological, patient and tumor characteristics. Dig Surg 2008, 25(1):21-26.
161. Li S, Liu Y, Shen Z: Characterization of Somatostatin Receptor 2 and 5 Expression in Operable Hepatocellular Carcinomas. Hepatogastroenterology 2012, 59(119).

162. Cebon J, Findlay M, Hargreaves C, Stockler M, Thompson P, Boyer M, Roberts S, Poon A, Scott AM, Kalff V, Garas G, Dowling A, Crawford D, Ring J, Basser R, Strickland A, Macdonald G, Green M, Nowak A, Dickman B, Dhillon H, Gebski V, Australasian Gastro-Intestinal Trials Group Ag HI: Somatostatin receptor expression, tumour response, and quality of life in patients with advanced hepatocellular carcinoma treated with long-acting octreotide. Br J Cancer 2006, 95(7):853-861.

163. D'Agostino L, Manguso F, Pivonello R, Colao A: The role of somatostatin analogs in the management of hepatocellular carcinoma. J Endocrinol Invest 2003, 26(8 Suppl):131-133.

164. Blaker M, Schmitz M, Gocht A, Burghardt S, Schulz M, Broring DC, Pace A, Greten H, De Weerth A: Differential expression of somatostatin receptor subtypes in hepatocellular carcinomas. J Hepatol 2004, 41(1):112-118.

165. Nguyen-Khac E, Ollivier I, Aparicio T, Moullart V, Hugentobler A, Lebtahi R, Lobry C, Susini C, Duhamel C, Hommel S, Cadranel JF, Joly JP, Barbare JC, Tramier B, Dupas JL: Somatostatin receptor scintigraphy screening in advanced hepatocarcinoma: A multi-center French study. Cancer Biol Ther 2009, 8(21):2033-2039.

166. Dimitroulopoulos D, Xinopoulos D, Tsamakidis K, Zisimopoulos A, Andriotis E, Panagiotakos D, Fotopoulou A, Chrysohoou C, Bazinis A, Daskalopoulou $D$, Paraskevas E: Long acting octreotide in the treatment of advanced hepatocellular cancer and overexpression of somatostatin receptors: randomized placebo-controlled trial. World J Gastroenterol 2007, 13(23):3164-3170.

167. Yao M, Wang L, Yan M, Yan X, Yao D: Insulin-Like Growth Factor-II: Molecular-Targeted Therapy for Hepatocellular Carcinoma. In chapter 13 2013.

168. Wu J, Zhu AX: Targeting insulin-like growth factor axis in hepatocellular carcinoma. J Hematol Oncol 2011, 4:30.

169. Imai K, Takaoka A: Comparing antibody and small-molecule therapies for cancer. Nat Rev Cancer 2006, 6(9):714-727.

170. Goetsch L, Corvaia N: Insulin-like growth factor receptor type I as a target for cancer therapy. Immunotherapy 2009, 1(2):265-279.

171. Pradhananga S, Wilkinson I, Ross RJ: Pegvisomant: structure and function. J Mol Endocrinol 2002, 29(1):11-14.

172. Divisova J, Kuiatse I, Lazard Z, Weiss H, Vreeland F, Hadsell DL, Schiff R, Osborne CK, Lee AV: The growth hormone receptor antagonist pegvisomant blocks both mammary gland development and MCF-7 breast cancer xenograft growth. Breast Cancer Res Treat 2006, 98(3):315-327.

173. Dagnaes-Hansen F, Duan H, Rasmussen LM, Friend KE, Flyvbjerg A: Growth hormone receptor antagonist administration inhibits growth of human colorectal carcinoma in nude mice. Anticancer Res 2004, 24(6):3735-3742.

174. McCutcheon IE, Flyvbjerg A, Hill H, Li J, Bennett WF, Scarlett JA, Friend KE: Antitumor activity of the growth hormone receptor antagonist pegvisomant against human meningiomas in nude mice. J Neurosurg 2001, 94(3):487-492

175. Gao J, Chesebrough JW, Cartlidge SA, Ricketts SA, Incognito L, VeldmanJones M, Blakey DC, Tabrizi M, Jallal B, Trail PA, Coats S, Bosslet K, Chang YS: Dual IGF-I/II-neutralizing antibody MEDI-573 potently inhibits IGF signaling and tumor growth. Cancer Res 2011, 71(3):1029-1040.

176. Alami N, Page V, Yu Q, Jerome L, Paterson J, Shiry L, Leyland-Jones B: Recombinant human insulin-like growth factor-binding protein 3 inhibits tumor growth and targets the Akt pathway in lung and colon cancer models. Growth Horm IGF Res 2008, 18(6):487-496.

177. Arnaldez Fl, Helman LJ: Targeting the insulin growth factor receptor 1. Hematol Oncol Clin North Am 2012, 26(3):527-542.

178. Rowinsky EK, Youssoufian H, Tonra JR, Solomon P, Burtrum D, Ludwig DL: IMC-A12, a human IgG1 monoclonal antibody to the insulin-like growth factor I receptor. Clin Cancer Res 2007, 13(18 Pt 2):5549s-5555s.

179. Burtrum D, Zhu Z, Lu D, Anderson DM, Prewett M, Pereira DS, Bassi R, Abdullah R, Hooper AT, Koo H, Jimenez X, Johnson D, Apblett R, Kussie P, Bohlen $P$, Witte L, Hicklin DJ, Ludwig DL: A fully human monoclonal antibody to the insulin-like growth factor I receptor blocks liganddependent signaling and inhibits human tumor growth in vivo. Cancer Res 2003, 63(24):8912-8921.

180. Yeh J, Litz J, Hauck P, Ludwig DL, Krystal GW: Selective inhibition of SCLC growth by the A12 anti-IGF-1R monoclonal antibody correlates with inhibition of Akt. Lung Cancer 2008, 60(2):166-174. 
181. Wang Z, Chakravarty G, Kim S, Yazici YD, Younes MN, Jasser SA, Santillan AA, Bucana CD, El-Naggar AK, Myers JN: Growth-inhibitory effects of human anti-insulin-like growth factor-I receptor antibody (A12) in an orthotopic nude mouse model of anaplastic thyroid carcinoma. Clin Cancer Res 2006, 12(15):4755-4765.

182. Allen GAE, Modhia F, Ludwig D, Hicklin D, Harari P: Inhibition of insulin-like growth factor-1 receptor signaling impairs proliferation of head and neck, lung, prostate and breast cancer cells [Abstract]. Proc Amer Assoc Cancer Res 2005, 46.

183. Wu KZL, Zhang K, Burtrum D, Ludwig DL, Moore MAS: A humanized insulin-like growth factor I receptor antibody inhibits multiple myeloma cell growth in vivo through anti-angiogenesis [Abstract]. Proc Am Assoc Cancer Res 2005, 46.

184. Abou-Alfa GK, Capanu M, O'Reilly EM, Ma J, Chou JF, Gansukh B, Shia J, Kalin M, Katz S, Abad L, Reidy-Lagunes DL, Kelsen DP, Chen HX, Saltz LB: A phase II study of cixutumumab (IMC-A12, NSC742460) in advanced hepatocellular carcinoma. J Hepatol 2014, 60(2):319-324.

185. Mulvihill MJ, Cooke A, Rosenfeld-Franklin M, Buck E, Foreman K, Landfair D, O'Connor M, Pirritt C, Sun Y, Yao Y, Arnold LD, Gibson NW, Ji QS: Discovery of OSI-906: a selective and orally efficacious dual inhibitor of the IGF-1 receptor and insulin receptor. Future Med Chem 2009, 1(6):1153-1171.

186. Zhao H, Desai V, Wang J, Epstein DM, Miglarese M, Buck E: Epithelialmesenchymal transition predicts sensitivity to the dual IGF-1R/IR inhibitor OSI-906 in hepatocellular carcinoma cell lines. Mol Cancer Ther 2012, 11(2):503-513.

187. Laursen T, Jorgensen JO, Christiansen JS: The management of adult growth hormone deficiency syndrome. Expert Opin Pharmacother 2008, 9(14):2435-2450.

188. Li RS, Pourpak A, Morris SW: Inhibition of the Insulin-like Growth Factor-1 Receptor (IGF1R) Tyrosine Kinase as a Novel Cancer Therapy Approach. J Med Chem 2009, 52(16):4981-5004

189. Bruns C, Lewis I, Briner U, Meno-Tetang G, Weckbecker G: SOM230: a novel somatostatin peptidomimetic with broad somatotropin release inhibiting factor (SRIF) receptor binding and a unique antisecretory profile. Eur J Endocrinol 2002, 146(5):707-716.

190. Theodoropoulou M, Stalla GK: Somatostatin receptors: From signaling to clinical practice. Front Neuroendocrinol 2013, 34(3):228-252.

191. Florio T: Molecular mechanisms of the antiproliferative activity of somatostatin receptors (SSTRs) in neuroendocrine tumors. Front Biosci 2008, 13:822-840.

192. Ferone D, Gatto F, Arvigo M, Resmini E, Boschetti M, Teti C, Esposito D, Minuto F: The clinical-molecular interface of somatostatin, dopamine and their receptors in pituitary pathophysiology. J Mol Endocrinol 2009 42(5):361-370.

193. Susini C, Buscail L: Rationale for the use of somatostatin analogs as antitumor agents. Ann Oncol 2006, 17(12):1733-1742.

194. Grozinsky-Glasberg S, Shimon I, Korbonits M, Grossman AB: Somatostatin analogues in the control of neuroendocrine tumours: efficacy and mechanisms. Endocr Relat Cancer 2008, 15(3):701-720.

195. Rinke A, Muller HH, Schade-Brittinger C, Klose KJ, Barth P, Wied M, Mayer C, Aminossadati B, Pape UF, Blaker M, Harder J, Arnold C, Gress T, Arnold R: Placebo-controlled, double-blind, prospective, randomized study on the effect of octreotide LAR in the control of tumor growth in patients with metastatic neuroendocrine midgut tumors: a report from the PROMID Study Group. J Clin Oncol 2009, 27(28):4656-4663.

196. Tsagarakis NJ, Drygiannakis I, Batistakis AG, Kolios G, Kouroumalis EA Octreotide induces caspase activation and apoptosis in human hepatoma HepG2 cells. World J Gastroenterol 2011, 17(3):313-321.

197. Jia WD, Xu GL, Xu RN, Sun HC, Wang L, Yu JH, Wang J, Li JS, Zhai ZM, Xue Q: Octreotide acts as an antitumor angiogenesis compound and suppresses tumor growth in nude mice bearing human hepatocellular carcinoma xenografts. J Cancer Res Clin Oncol 2003, 129(6):327-334.

198. Engel JB, Schally AV, Halmos G, Baker B, Nagy A, Keller G: Targeted therapy with a cytotoxic somatostatin analog, $\mathrm{AN}-238$, inhibits growth of human experimental endometrial carcinomas expressing multidrug resistance protein MDR-1. Cancer 2005, 104(6):1312-1321.

199. Nagy A, Schally AV, Halmos G, Armatis P, Cai RZ, Csernus V, Kovacs M, Koppan M, Szepeshazi K, Kahan Z: Synthesis and biological evaluation of cytotoxic analogs of somatostatin containing doxorubicin or its intensely potent derivative, 2-pyrrolinodoxorubicin. Proc Natl Acad Sci U S A 1998, 95(4):1794-1799.
200. Xie Y, Chen S, Wang CH, Tang CW: SOM230 combined with celecoxib prolongs the survival in nude mice with HepG-2 xenografts. Cancer Biol Ther 2011, 12(1):86-92.

201. Chen S, Xie Y, Wang CH, Tang CW: [Effects of octreotide on necrosis of hepatocellular carcinoma xenografts in nude mice]. Ai Zheng 2009, 28(7):673-678

202. Xie $Y$, Chen S, Wang CH, Tang CW: [Induction of necrosis in the hepatocellular carcinoma HepG2 xenografts treated with SOM230]. Zhonghua Gan Zang Bing Za Zhi 2009, 17(10):759-764.

203. Lawnicka H, Stepien H, Wyczolkowska J, Kolago B, Kunert-Radek J, Komorowski $\mathrm{J}$ : Effect of somatostatin and octreotide on proliferation and vascular endothelial growth factor secretion from murine endothelial cell line (HECa10) culture. Biochem Biophys Res Commun 2000, 268(2):567-571.

204. Danesi R, Agen C, Benelli U, Paolo AD, Nardini D, Bocci G, Basolo F, Campagni A, Tacca MD: Inhibition of experimental angiogenesis by the somatostatin analogue octreotide acetate (SMS 201-995). Clin Cancer Res 1997, 3(2):265-272.

205. Watson JC, Balster DA, Gebhardt BM, O'Dorisio TM, O'Dorisio MS, Espenan GD, Drouant GJ, Woltering EA: Growing vascular endothelial cells express somatostatin subtype 2 receptors. Br J Cancer 2001, 85(2):266-272.

206. Borbath I, Leclercq IA, Sempoux C, Abarca-Quinones J, Desaeger C, Horsmans Y: Efficacy of lanreotide in preventing the occurrence of chemically induced hepatocellular carcinoma in rats. Chem Biol Interact 2010, 183(1):238-248.

207. Raderer M, Hejna MH, Kurtaran A, Kornek GV, Valencak JB, Oberhuber G, Vorbeck F, Virgolini I, Scheithauer W: Successful treatment of an advanced hepatocellular carcinoma with the long-acting somatostatin analog lanreotide. Am J Gastroenterol 1999, 94(1):278-279.

208. Siveke JT, Herberhold C, Folwaczny C: Complete regression of advanced HCC with long acting octreotide. Gut 2003, 52(10):1531.

209. Deming DA, Stella AL, Holen KD, Ku G, O'Reilly EM: A dramatic response to long-acting octreotide in metastatic hepatocellular carcinoma. Clin Adv Hematol Oncol 2005, 3(6):468-472. discussion 472-464.

210. Borbath I, Lhommel R, Guiot Y, Coche E, Sempoux C: Lanreotide treatment of metastatic hepatocellular carcinoma resulting in partial regression and more than 3 years of progression-free survival. Acta Gastroenterol Belg 2012, 75(2):270-273.

211. Dimitroulopoulos D, Xinopoulos D, Tsamakidis K, Zisimopoulos A, Andriotis E, Markidou S, Panagiotakos D, Chrysohoou C, Bazinis A, Paraskevas E: The role of sandostatin LAR in treating patients with advanced hepatocellular cancer. Hepatogastroenterology 2002, 49(47):1245-1250.

212. Gill ML, Atiq M, Sattar S, Khokhar N: Treatment outcomes with long acting octreotide in inoperable hepatocellular carcinoma: a local experience and review of literature. J Pak Med Assoc 2005, 55(4):135-138,

213. Samonakis DN, Moschandreas J, Arnaoutis T, Skordilis P, Leontidis C, Vafiades I, Kouroumalis E: Treatment of hepatocellular carcinoma with long acting somatostatin analogues. Oncol Rep 2002, 9(4):903-907.

214. Plentz RR, Tillmann HL, Kubicka S, Bleck JS, Gebel M, Manns MP, Rudolph KL: Hepatocellular carcinoma and octreotide: treatment results in prospectively assigned patients with advanced tumor and cirrhosis stage. J Gastroenterol Hepatol 2005, 20(9):1422-1428.

215. Schoniger-Hekele M, Kettenbach J, Peck-Radosavljevic M, Muller C: Octreotide treatment of patients with hepatocellular carcinoma-a retrospective single centre controlled study. J Exp Clin Cancer Res 2009, 28:142.

216. Slijkhuis WA, Stadheim L, Hassoun ZM, Nzeako UC, Kremers WK, Talwalkar JA, Gores GJ: Octreotide therapy for advanced hepatocellular carcinoma. J Clin Gastroenterol 2005, 39(4):333-338.

217. Pivonello R, Di Sarno A, Vitale G, Ferraioli G, Guerra E, de Stefano G, Lombard G, Giorgio A, Hofland LJ, Colao A: Somatostatin analogs in the treatment of hepatocellular carcinoma: correlation between sst 2 receptor expression and patients'survival [abstract]. Endocr Rev 2006, P3 613

218. Del Prete S, Montella L, Caraglia M, Maiorino L, Cennamo G, Montesarchio V, Piai G, Febbraro A, Tarantino L, Capasso E, Palmieri G, Guarrasi R, Bianco M, Mamone R, Savastano C, Pisano A, Vincenzi B, Sabia A, D'Agostino A, Faiola V, Addeo R: Sorafenib plus octreotide is an effective and safe treatment in advanced hepatocellular carcinoma: multicenter phase II So.LAR. study. Cancer Chemother Pharmacol 2010 66(5):837-844.

219. Caraglia M, Giuberti G, Marra M, Addeo R, Montella L, Murolo M, Sperlongano P, Vincenzi B, Naviglio S, Prete SD, Abbruzzese A, Stiuso P: Oxidative stress and ERK $1 / 2$ phosphorylation as predictors of outcome 
in hepatocellular carcinoma patients treated with sorafenib plus octreotide LAR. Cell Death Dis 2011, 2:e150.

220. Kouroumalis E, Skordilis P, Thermos K, Vasilaki A, Moschandrea J, Manousos ON: Treatment of hepatocellular carcinoma with octreotide: a randomised controlled study. Gut 1998, 42(3):442-447.

221. Yuen MF, Poon RT, Lai CL, Fan ST, Lo CM, Wong KW, Wong WM, Wong BC A randomized placebo-controlled study of long-acting octreotide for the treatment of advanced hepatocellular carcinoma. Hepatology 2002, 36(3):687-691.

222. Janson ET, Westlin JE, Eriksson B, Ahlstrom H, Nilsson S, Oberg K: [111lnDTPA-D-Phe1]octreotide scintigraphy in patients with carcinoid tumours: the predictive value for somatostatin analogue treatment. Eur J Endocrinol 1994, 131(6):577-581.

223. Becker G, Allgaier HP, Olschewski M, Zahringer A, Blum HE, Group HS: Long-acting octreotide versus placebo for treatment of advanced HCC: a randomized controlled double-blind study. Hepatology 2007, 45(1):9-15.

224. Barbare JC, Bouche O, Bonnetain F, Dahan L, Lombard-Bohas C, Faroux R, Raoul JL, Cattan S, Lemoine A, Blanc JF, Bronowicki JP, Zarski JP, Cazorla S, Gargot D, Thevenot T, Diaz E, Bastie A, Aparicio T, Bedenne L: Treatment of advanced hepatocellular carcinoma with long-acting octreotide: a phase III multicentre, randomised, double blind placebo-controlled study. Eur J Cancer 2009, 45(10):1788-1797.

doi:10.1186/1750-9378-9-27

Cite this article as: Pivonello et al:: The GH-IGF-SST system in hepatocellular carcinoma: biological and molecular pathogenetic mechanisms and therapeutic targets. Infectious Agents and Cancer 2014 9:27.

\section{Submit your next manuscript to BioMed Central and take full advantage of:}

- Convenient online submission

- Thorough peer review

- No space constraints or color figure charges

- Immediate publication on acceptance

- Inclusion in PubMed, CAS, Scopus and Google Scholar

- Research which is freely available for redistribution 